\title{
Fracture aquifers identification in the Zou basin (West Africa) using Remote sensing and GIS
}

Francis E. Oussou, Nicaise Yalo , Christopher E. Ndehedehe , Joseph Oloukoi , Abdoukarim Alassane, Moussa Boukari \& Vinel G.H. Gbèwézoun

To cite this article: Francis E. Oussou, Nicaise Yalo, Christopher E. Ndehedehe, Joseph Oloukoi , Abdoukarim Alassane, Moussa Boukari \& Vinel G.H. Gbèwézoun (2020): Fracture aquifers identification in the Zou basin (West Africa) using Remote sensing and GIS, Geocarto International, DOI: 10.1080/10106049.2020.1852613

To link to this article: https://doi.org/10.1080/10106049.2020.1852613

Accepted author version posted online: 19

Nov 2020.

Submit your article to this journal $₫$

山 Article views: 24

Q View related articles $\sqsubset$

View Crossmark data ־ 


\title{
Fracture aquifers identification in the Zou basin (West Africa) using Remote sensing and GIS
}

\author{
Francis E. Oussou ${ }^{\mathrm{a}^{*}}$, Nicaise Yalo ${ }^{\mathrm{a}}$, Christopher E. Ndehedehe ${ }^{\mathrm{b}, \mathrm{c}}$, Joseph Oloukoi ${ }^{\mathrm{d}}$, Abdoukarim \\ Alassane $^{\mathrm{a}}$, Moussa Boukari ${ }^{\mathrm{a}}$, Vinel G.H. Gbèwézoun ${ }^{\mathrm{a}}$ \\ ${ }^{a}$ Laboratoire d'Hydrologie Appliquée, Institut National de l'Eau (INE), Université d'Abomey-Calavi, \\ 01BP526 - Cotonou, Bénin.
}
${ }^{\mathrm{b}}$ School of Environment \& Science, Griffith University, Nathan, Queensland 4111, Australia.
${ }^{c}$ Australian Rivers Institute and Griffith School of Environment \& Science, Griffith University, Nathan, Queensland 4111, Australia.
${ }^{\mathrm{d}}$ African Regional Institute for Geospatial Information Science and Technology (AFRIGIST), Obafemi Awolowo University Campus, PMB 5546, Ile-Ife, Nigeria

*Corresponding author: (F.E. Oussou) francisoussou@gmail.com.

\begin{abstract}
The riparian communities of the Zou basin of West Africa rely heavily on drinking water supplied by fractured aquifer systems. This study aims to provide accurate fracture maps and derived products (fracture density, coincidence map and cross-points) using Landsat 8 (visible and infrared bands) and PALSAR DEM datasets with borehole data collected from the national integrated database. Digital image processing techniques through image enhancement and directional Sobel filters application were used to analyse Landsat 8 and PALSAR data. Results show that the main orientations of fractures are N10-N20, N90-N100 and N180 for the visible, 10-N20, N40-N50, N90, N140 and N180 for the infrared and for the PALSAR DEM, they are N10-N20, N90-N100 and N170-N180. The fracture length overall interval is 0.15 to $21.2 \mathrm{~km}$ and the cumulative length of each fracture map is adjusted to power law with characteristic of exponent respectively $0.86,0.91$ and 0.96 . The chi square $\left(\chi^{2}\right)$ test of cumulative length versus class frequency reveals a significant relationship for the visible and PALSAR fracture maps. Although, the calculated $\chi^{2}$ is greater than the theoretical chi square for the infrared, there is a strong and positive correlation for the three fracture maps $(0.94,0.99$ and 0.98$)$. More than $50 \%$ of the fracture cross-points (CP) occurs with the North-South (NS) orientations. The coincidence map analysis shows that the PALSAR fracture map has the highest ratio of 0.88 , proving it should prioritize over the visible and infrared maps. High flow $(\mathrm{Q}>5$ cubic $\mathrm{m} / \mathrm{h}$ ) boreholes located near the N10, N20 and N180 main orientations are more than 50\% confirming their significant contribution to aquifers' productivity. The spatial and statistical analysis of these fractured aquifers are critical to improve drinking water access and water resources planning for the basin communities.
\end{abstract}

Keywords: Drinking water, aquifer system, fracture map, groundwater flow, Zou basin

\section{Introduction}

Aquifers are geological formations capable of bearing significant underground water flow depending on their geometric and hydrodynamic properties. The basement aquifers from the surface to the bottom consist of weathered layer and a bottom fractured layer that concentrates most of the groundwater (Biemi, 1992; Savané, 1997; Wyns \& al., 2004 and Lachassagne \& al., 2011 cited by Tagnon \& al., 2016). For the management and monitoring of these resources, Remote sensing data offer an appropriate spectral and spatial resolution for better hydrogeological surveys (Bruning, \& al., 2009). Lineaments extraction through Remote sensing technics has been recognized as an efficient way toward hydrogeological knowledge improvement because of the possibility to exhibit geological fractures that shelter groundwater (Das, 1990) and even more structural elements 
enhancement from satellite images lead to a better geological accidents mapping (Youan Ta \& al., 2008). Therefore, in bedrock areas, for example, different type of satellite images and aerial photographs have been used for multiple purposes such as groundwater potential evaluation and fractures network identification (Boukari, 1982; Kouamé \& al., 2009; Yao \& al., 2014; Ndong \& al., 2014; Assatse \& al., 2016; Tagnon \& al., 2016, Oussou \& al., 2019). Furthermore, Remote sensing satellite observations such as Landsat 7 ETM+ have been successfully used in the eastern Tauride belt (SE Turkey) to isolate hydrothermally altered rocks by applying the Crosta techniques (Aydal et al., 2007). This progress further highlights the importance of Remote sensing as an emerging geospatial tool in hydrogeological and geophysical exploration studies.

Fractured aquifers cover more than $80 \%$ of the national territory of Benin republic and require a better understanding of their geometry for more reliable exploitation. For several decades, many authors have worked on this basement area in general and showed several proofs on the complexity of the geological formations and its richness with different type of minerals (e.g., Pougnet, 1957, Bonhomme, 1962, Boussari \& Rollet, 1974, Boukari, 1982 and Adissin Glodji, 2012, d'Almeida \& al., 2015). As the tectonic events affect the geology in different ways, the fractures network produced is either hydraulically active or has no hydrogeological interest (Lasm, 2000). Fractures located beneath the weathered layer are challenging to be detected but geophysics, photointerpretation and remote sensing methods provide significant information about their hidden geometries (Lasm, 2000). Even more, Bourguet \& al. (1980-1981) showed that there is a considerable correlation between the alteration thickness and the underlying fractured aquifer layer. From these evidences, the obvious recommendation to access aquifers in basement areas is to not only produce an accurate fracture maps but also analyse the existing boreholes lithology $(20.5 \pm 8.3$ m) to identify high alteration thickness areas (Oussou \& al., 2019).

Apart from low groundwater potential areas, drinking water supply in Benin (Fig. 1) is essentially drawn from aquifers (Boukari, 1998). Future projection of all water demand in 2025 shows that less than $18 \%$ of groundwater available and less than $40 \%$ of surface water will be required in the country (Vision Eau 2025, 1999). Therefore, there is no compelling water scarcity concern in a near future (Boukari, 2002) but the increasing number of dried up and low productivity boreholes is an obvious challenge that water supply departments face daily. Furthermore, as the country is mainly covered by basement geological formations, the critical challenge remains aquifer's geometry and hydrodynamics properties evaluation for reliable borehole implantation. One of the ongoing governments' process-based initiative in water sector is to move from smaller drinking water supply systems to bigger ones where many villages can benefit from the same water supply system managed by multi-national companies. In fact, this target to be reached requires highly productive aquifers which are not easy to be found in hard rock areas. The annual rainfall might be large enough, but the ratio of surface runoff and infiltration is clearly against aquifers recharge, which is a main parameter for sustainable water supply in the basin (Awoyé, 2007). Aquifer systems across the world are indeed complex and understanding their groundwater-surface water interactions on a large-scale is even more difficult. Satellite gravity methods (e.g., Gravity Recovery and Climate Experiment) have emerged as new tools to study the response of aquifer and groundwater processes to the composite influence of extreme droughts and water extraction on a relatively larger scale (e.g., Ojha et al., 2019; Ferreira et al., 2018; Ndehedehe et al., 2017; Ndehedehe et al., 2020). However, knowledge on recharge and discharge mechanisms is still limited because of the coarse resolution of these satellite gravimetric methods. Considering complex recharge processes as noted here in Benin, new techniques to assess the status of aquifers and support reasonable management of groundwater resources for domestic application is crucial.

To fill some of these gaps in the Zou basin and also complement past studies in the region (Boukari, 1982; Adissin, 2012; Oussou \& al., 2019), this study combines radar, and optical (infrared and visible remote sensing) datasets in a Geographical Information System (GIS) to provide a pattern for high productivity aquifers identification. The processing of satellite remote sensing image is 
employed to depict the hydrogeological conditions for better groundwater exploitation and decrease significantly the drinking water production cost in remote areas (Meijerink, 2007, Dewandel \& al., 2006 and Becker, 2006).

In this study, the overarching goal is to update the catchment fracture map by integrating GIS with remote sensing techniques. To this end, secondary products such as fracture density, coincidence map and cross-points are derived. The aquifers hydrodynamic properties are analysed using GIS techniques in order to facilitate borehole implantation for drinking water supply. The methods, analyses and results are detailed and discussed in what follows.

\section{Study area}

Zou catchment is located between latitudes $7^{\circ}$ and $8^{\circ} 33^{\prime}$ North and longitudes $1^{\circ} 35^{\prime}$ and $2^{\circ} 30^{\prime}$ East. At the latitude of Doume-Lakoun till Kitikpli, 2.2\% of the basin covers the Togolese territory (Fig. 1). Communes such as Savalou (31.0\%) and Bantè (24.7\%) are mainly represented. The basin is relatively well watered as it is characterized by an intermediate climate between the subequatorial climate of the coast and the Sudano Sahelian one of the North parts of Benin (Boko, 1988; BokononGanta; 1987; Afouda, 1990; Houssou, 1998). The basin represents essentially an area where the influences of the monsoon from South-West and the continental trade winds also known as harmattan of the North-East are blurred. The rainfall evolves from $18.3 \mathrm{~mm}$ at the end of the year to $172.9 \mathrm{~mm}$ in July. Many studies such as Alidou \& al., (1975), Boukari (1982), Breda (1985) and others show the high geological complexity of the area at the local and regional scale. Hence, the lithology and structure have been modified by several phases of deformation, metamorphism and magmatism. The basin surface is shaped by very old rocks dating from Precambrian (granite-gneissic basement).

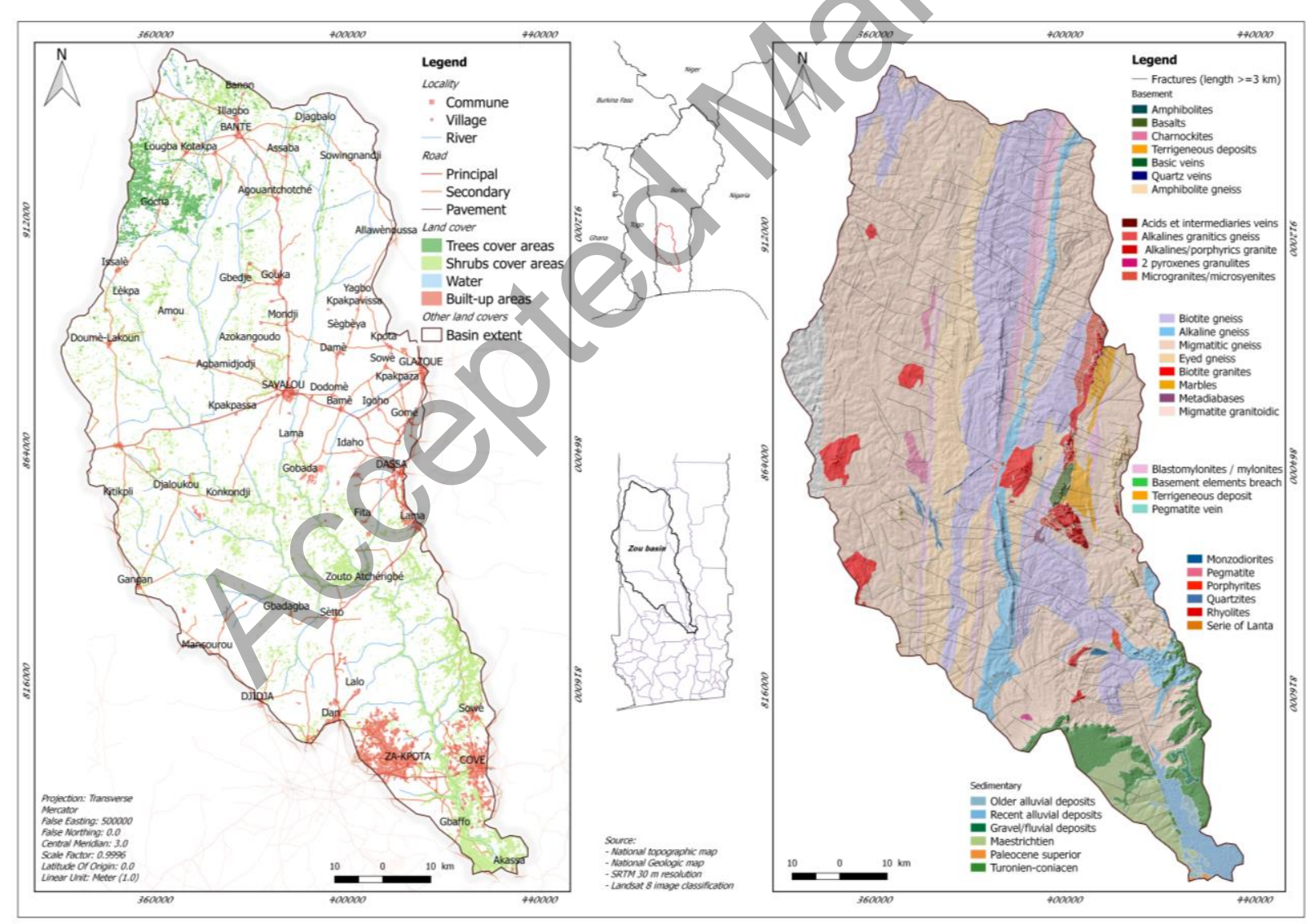

Figure 1: Geographical (left) and geological (right) maps of Zou basin 
The two geological map sheets (Breda, 1989) that cover the entire basin exhibit the metamorphic complex represented by five types of gneiss such as the migmatite gneisses (mgn), eyed biotite gneisses (gno), amphibolite and biotite gneisses (gnab), alkaline and pyroxene gneisses (gnp) and biotite and hypersthene gneisses. The Kandi shear zone (KSZ), grano-monzodioritic charnockites, which outcrop inside the migmatites, the marble and many other low proportion formations complete the list of the metamorphic rocks. Furthermore, the volcano-sedimentary series of Idaho-Mahou and Ouedo located respectively at the west and south of the study area (Fig.1) are composed of acid volcanic rocks (rhyolite and alkaline rhyolite), basic volcanic rocks (basalt and basaltic breccias) and also alkaline granites and microgranites (Boussari \& Rollet, 1974, Boukari, 1982). Some of the major plication structures are related to the eyed gneisses, which radius of curvature is plurikilometric and the vertical axial plane direction is north-south from N10 to N30 (Breda, 1989). The mylonitic bands cross the study area and are divided in 3 categories such as the western (N10), the central (N30) and the eastern band (N30). Consequently, the above-mentioned complexity governs the fracture maps spatial pattern whether in $2 \mathrm{D}$ or $3 \mathrm{D}$ and directly define the hydrogeological reservoirs flow occurrences.

\section{Methodology}

\section{Data collected}

Two scenes of $30 \mathrm{~m}$ spatial resolution in multispectral mode and $15 \mathrm{~m}$ in panchromatic mode were downloaded from the website https://earthexplorer.usgs.gov/ (Table 1). Spectral resolution of the Operational Land Imager-Thermal Infrared Sensors (OLI-TIRS) offers a possibility to evaluate the efficiency of the visible and infrared bands for lineaments identification in basement areas. The paths and rows are respectively 192-54 and 192-55 acquired on the 2014-12-28.

The radar dataset is from Advanced Land Observing Satellite-2 (ALOS-2) mission or Daichi2 which is a next step of the radar (L-SAR) sensor launching program realised by the Japanese Aerospace Exploration Agency (JAXA). The polarimetric Phased Array L-band Synthetic Aperture Radar (PALSAR-L) including the $12.5 \mathrm{~m}$ spatial resolution ALOS PALSAR DEM has been used in this study to complete the visible and infrared bands as the goal of the study is to find the best dataset for lineaments extraction. The data is downloaded from the Alaska Satellite Facility (ASF)

Distributed Active Archive Center (DAAC) data portal (ASF DAAC, 2015).

Table 1: Satellite datasets characteristics

\begin{tabular}{|c|c|c|c|c|c|}
\hline Sensors & Name & Mode & $\begin{array}{c}\text { Swath } \\
\text { width }\end{array}$ & $\begin{array}{c}\text { Spatial/ } \\
\text { (wavelengths) }\end{array}$ & $\begin{array}{c}\text { Temporal } \\
\text { resolution }\end{array}$ \\
\hline \multirow{2}{*}{ PALSAR } & AP_07598_FBD_F0120_RT1 & AP_07598_FBD_F0130_RT1 \\
& AP_07598_FBD_F0140_RT1 & $\begin{array}{c}\text { Dual } \\
\text { polarization } \\
\text { (HH and HV) }\end{array}$ & $70 \mathrm{~km}$ & L $(\lambda=\sim 23.5 \mathrm{~cm})$ & $\begin{array}{c}\text { Pixel: } 12.5 \\
\mathrm{~m}\end{array}$ \\
& AP_07598_FBD_F0160_RT1 & AP_08517_FBD_F0130_RT1 & & & \\
\hline
\end{tabular}




\begin{tabular}{|c|c|c|c|c|c|}
\hline & $\begin{array}{l}\text { AP_08517_FBD_F0140_RT1 } \\
\text { AP_08517_FBD_F0150_RT1 }\end{array}$ & & & & \\
\hline OLI-TIRS & $\begin{array}{l}\text { LC81920552014362LGN00 } \\
\text { LC81920542014362LGN00 }\end{array}$ & & $185 \mathrm{~km}$ & $\begin{array}{c}\text { Visible (B1 -B5) } \\
\text { and Infrared (B6- } \\
\text { B7, B9-B11) } \\
\text { Panchromatic } \\
\text { (B8) }\end{array}$ & $\begin{array}{l}30 \mathrm{~m} \text { and } \\
15 \mathrm{~m}\end{array}$ \\
\hline MODIS/Terra & $\begin{array}{c}\text { NOAA-AVHRR derived } \\
\text { NDVI and EVI }\end{array}$ & - & - & 36 bands & $\begin{array}{l}0.05^{\circ} / \\
16 \text { day }\end{array}$ \\
\hline
\end{tabular}

The Pira-Savè and Abomey-Zagnanado geological map sheets produced by Breda (1989) for "'Office Béninois des Mines', have been collected and georeferenced. Geological features such as fractures, shear zones, and geological formation outlines have been digitized. A total of 2371 boreholes data has been collected from the national database called " Base de donnée Intégrée (BDI) '. This study uses mainly the boreholes' flow attribute to analyse fractured aquifers' hydrodynamic. For validation purpose, the National Oceanic and Atmospheric Administration-Advanced Very High Resolution Radiometer (NOAA-AVHRR) derived Normalized Difference Vegetation Index (NDVI) and Enhanced Vegetation Index (EVI) time series are also retrieved from an USGS website (https://lpdaac.usgs.gov/products/mod13a2v006/).

\section{Lineaments identification}

A lineament is any kind of linear feature, which can be found in a satellite image or aerial photography. The features are geological limits, slope ruptures, the river path, man-made structures and fracture network areas (Biémi, 1992; Meijerink \& al. 2007, Bruning \& al., 2009). The lineament detection operation starts with the image enhancement. Hence, the image quality is increased using one of the spatial domain methods (e.g., mode filter, median filter, etc.) or frequency domain methods like the gaussian or Butterworh filter (Rahnama \& Gloaguen, 2014). Stretching contrasts increase the tone distribution between elements in an image, and further lighten bright areas while dark regions become more darkened. Notably, lineaments detection filters are separated in three categories: gradient filters like Sobel (Table 3) and Prewitt, Laplacian filter (LOG) and optimal filter Canny. Differentiation, smoothing and labelling are applied to the filtered images to obtain the lineaments map (Marr \& Hildreth, 1980, Canny, 1986; Deriche, 1987; Ziou, 1991 cited by Rahnama \& Gloaguen, 2014).

The visible and infrared bands (LANDSAT-8) are processed in remote sensing softwares (ENVI 5.1 and PCI Geomatica). The Principal Components and Convolution/Morphology filter tools are used to process both the visible and infrared stacked bands. The result of the Principal component 1 (PC 1) is then transferred to PCI Geomatica where the module 'LINE' algorithm (Table 2) is applied to extract the lineament features which in turn is converted into GIS well-known format shapefile for further spatial analysis. The trial version of PCI Geomatica software is used for semiautomatic linear features extraction and was made available after a request addressed to the software developer (http://www.pcigeomatics.com). The algorithm parameters are adapted to this study area based on the recommendation of Shankar \& al. (2016) and El-Sawy \& al. (2016). 
Table 2: Line module parameter values

\begin{tabular}{|c|c|c|c|}
\hline Parameters & $\begin{array}{c}\text { Suggested } \\
\text { value }\end{array}$ & Parameters & $\begin{array}{c}\text { Suggested } \\
\text { value }\end{array}$ \\
\hline $\begin{array}{c}\text { Filter radius } \\
\text { (RADI) }\end{array}$ & 50 & $\begin{array}{c}\text { Line fitting error } \\
\text { threshold (FTHR) }\end{array}$ & 7 \\
\hline $\begin{array}{c}\text { Gradient threshold } \\
\text { (GTHR) }\end{array}$ & 100 & $\begin{array}{c}\text { Angular difference } \\
\text { threshold (ATHR) }\end{array}$ & 30 \\
\hline $\begin{array}{c}\text { Length threshold } \\
\text { (LTHR) }\end{array}$ & 30 & $\begin{array}{c}\text { Linking distance } \\
\text { threshold (DTHR) }\end{array}$ & 50 \\
\hline
\end{tabular}

According to Pirotti and Tarolli (2010); Tarolli \& al. (2012); Persendt and Gomez (2016); Niipele \& Chen (2019), DEM features extraction, Earth Observation (EO) derived information will assist for better understanding of the environment and its operating systems such as fractured aquifers in this case. The steps for the PALSAR DEM processing consist of basic corrections, the Sobel filter application and lineaments extraction using the Line module. The directional filters Sobel highlight strong transitions reflectance and high spatial frequencies generally associated with lineaments. Four directions filters have been applied to the pre-processed bands.

Table 3: Sobel kernels in four directions (El-Sawy \& al., 2016)

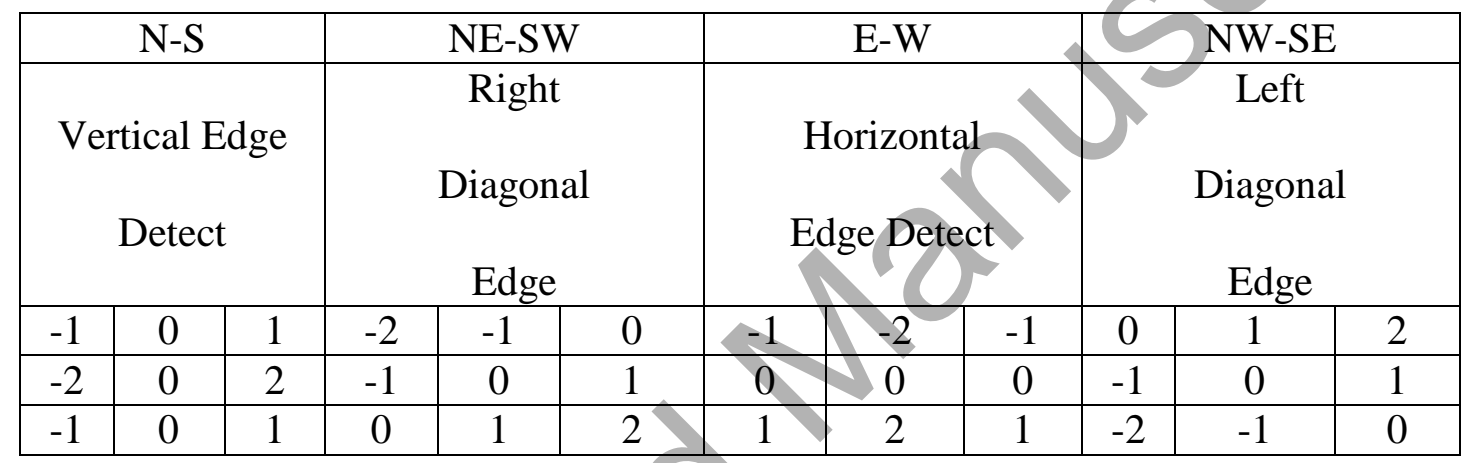

\section{Fractures' length statistical adjustment}

The cumulative length (CL) of each fracture map is adjusted to the power law, which has been used in the past works (Jourda, 2005, Koudou \& al., 2013 and Tagnon \& al., 2016). Short fracture lengths (less than $1.28 \mathrm{~km}$ ) are affected by the problem of "Truncation " effect and the longer one (greater than $13.04 \mathrm{~km}$ ) by "'censoring " effects (Ackermann \& al., 2001 and Zazoun, 2008). Thus, the power law has been adjusted to the recommended interval $(1.28 \mathrm{~km} \leq \mathrm{l} \leq 13.04 \mathrm{~km})$ and the chi square $\left(\chi^{2}\right)$ test used to evaluate the relationship significance in the data.

$$
C_{t}=a \times l^{\alpha}
$$

With $C_{t}$ : class frequency, $a$ : proportionality coefficient and $\alpha$ : ‘characteristic

\section{Nearest Neighbour Analysis}

The analysis concerns point-to-point and origin-to-point nearest neighbour statistic. The first ratio $(\widehat{G}(h))$ has been calculated by dividing a nearest neighbour distance $\left(l_{i}\right)$ sum from the $i^{t h}$ centroid to the nearest one in a region by $n$ the total number of points within a distance $(h)$. The second one origin-to-point is an equivalent analysis where distance $\left(l_{i}\right)$ from $\mathrm{m}$ random origins are compared to the nearest neighbours (Tran, 2004). 


$$
\widehat{G}(h)=\frac{1}{n} * \sum_{l_{i} \leq h} 1 \text { or } \hat{F}(h)=\frac{1}{m} * \sum_{l_{i} \leq h} 1
$$

With ArcGIS tool "Average Nearest Neighbour "' (Fig. 2), the fracture map from each satellite image is processed to evaluate the spatial pattern. For the PALSAR L-band extracted lineaments, the average nearest neighbour summary shows a clustered pattern and a very low z-score (-55.2) which means that there is less than $1 \%$ likelihood that the clustered pattern could be the result of random chance.

\section{Fracture density and cross-points}

Fracture density (FracDen) is formulated as total fracture length or counts per unit area (in 2D) or per unit volume (in 3D). This type of analysis is useful to find out major fracture populated area for high flow aquifers identification in hard rocks areas (Tran, 2004). A cross-point (CP) is the point of intersection between fractures where groundwater flow occurrence might be very interesting for water supply (Tagnon et al., 2016). The open source software QGIS tool ' Line intersection "' is used to generate the cross-points.

$$
\begin{gathered}
\text { FracDen }(2 D)=\frac{2 * \sum_{i} \operatorname{Rad}_{i}}{\text { Model area }} \\
\text { FracDen }(3 D)=\frac{\pi * \sum_{i}\left(\operatorname{Rad}_{i}\right)^{2}}{\text { Model volume }}
\end{gathered}
$$

Where $\sum_{i} \operatorname{Rad}_{i}$ is the total fracture length or count.

\section{Coincidence analysis}

According to Magowe and Carr (1997), a lineament interpreted in two or more images is a coincident lineament. Groundwater prospecting in the basement areas requires a clear idea about the fracture network. Based on the works of Bruning \& al. (2009) and Alonso-Contes (2011), the coincidence map provides a sure and consistent highlight of areas that have undergone tectonic actions where groundwater flows probably occur. In this study, three categories of spectral bands are considered to maximize the chance to retrieve the most accurate fracture map of the basin. The steps involved in this process are, to: (1) generate a buffer of acceptable size representing on average the zones of fractures, (2) verify all the interpreted lineaments, (3) perform a GIS analysis to filter the interpretations and (4) analyse the performance of the coincidence map.

Guiraud and Alidou (1981), Boukari (1982), Adissin (2012) and several works undertaken in this basement are considered to have the size of the buffer. However, a detailed study on the width of the faults in the basin is missing. At the level of a fracture it is conceivable that the zone of influence is beyond the normal size of the fracture. The size of the buffers around the lineaments is then fixed at $200 \mathrm{~m}$. The buffer generated from the 3 layers of lineaments are converted into raster format and reclassified into a binary image. The sum of the binary images gives the number of times the lineaments coincide and therefore the coincidence map of lineament is generated (Table 6). The minimum degree of coincidence is fixed at 2 to make the fracture map more accurate. The retained buffer area for a fracture map is divided by that of the total filtered area after overlapping the three fracture maps to obtain a ratio which in turn is used for ranking.

For the lineaments' coincidence validation purpose, the Normalized Difference Vegetation Index and Enhanced Vegetation Index time series derived from MODIS products MOD13A2 (Didan, 2015) are used to compare the temporal change of vegetation greenness over areas mapped as 
coincidence areas and non-coincidence areas. A QGIS software extension called 'Temporal/Spectral Profile Tool' ' is used to extract the NDVI time series from the MODIS vegetation greenness dataset (a netcdf4 file format). After plotting, vegetation greenness turns out to be higher in the buffer zones. The principal component analysis (PCA, e.g., Jolliffe 2002) of the series is computed in order to identify the temporal pattern of the vegetation greenness trend from 2002 to 2019. The PCA is an extraction technique that reduces the dimensions of multivariate data by creating new sets of variables that are linear combinations of the original variable (e.g., Jolliffe, 2002). Given that it helps to account for the most variability in the data (e.g., Ndehedehe et al., 2020), the method was used in this study to isolate dominant modes of orthogonal variability in vegetation greenness.

\section{Results and Discussion}

\section{Fracture maps statistics}

The maps statistics reveal a minimum and maximum fracture length from 0.8 to $15.8 \mathrm{~km}$ for the visible, 0.3 to $21.2 \mathrm{~km}$ for the infrared and for the PALSAR image dataset from 0.15 to $11.2 \mathrm{~km}$. The longest lineament is in granulite biotite gneiss (gngr) for the visible fracture map, in mainly amphibolite and biotite gneiss (gnab) for the infrared fracture map and for the PALSAR fracture map in alkalin gneiss (gnp). The infrared fracture map has the highest average and standard deviation (Table 4) meaning that it tends to depict high length fractures and there is an inconsistency in the distribution. The lowest length average and standard deviation are recorded on the PALSAR fracture map. The low standard deviation reveals a consistency of the fracture's length distribution and more, longer fractures are generally broken in smaller sub-orientations. In the case of the visible fracture map, the average and standard deviation are respectively $1.89 \mathrm{~km}$ and $1.15 \mathrm{~km}$.

For a significance level of 0.05 and a degree of freedom of 17, the calculated chi square $\left(\chi^{2}\right)$ for the visible and PALSAR fracture maps are greater than the theoretical $\chi^{2}$. This means that the power law adjustment represents the significant relationship between the fracture length and class frequency per orientation. The calculated $\chi^{2}$ for the infrared fracture map is less than the theoretical $\chi^{2}$ value of 27.59. The fit test shows in this case that the distribution pattern is random and cannot be explained by any standard law.

Table 4: Summary of statistical data for lineaments length and count

\begin{tabular}{|c|c|c|c|c|}
\hline Dataset & Count & Average & $\begin{array}{c}\text { Standard } \\
\text { deviation }\end{array}$ & $\boldsymbol{\chi}^{\mathbf{2}}$ \\
\hline Visible & 4595 & 1.89 & 1.15 & 61.46 \\
\hline Infrared & 5344 & 2.2 & 1.4 & 21.91 \\
\hline PALSAR & 31092 & 1.1 & 0.82 & 37.07 \\
\hline
\end{tabular}

The correlation coefficients of the three fracture maps are strong and positive, indicating values of 0.94, 0.99 and 0.98, respectively (Fig. 2). This relationship is an indicator of how fracture abundance in an area can be revealing of the relatively high probability of significant groundwater flow. The adjustment to the power law gives a characteristic of exponent value of $0.86,0.91$ and 0.96 , respectively for the visible, infrared and PALSAR. 


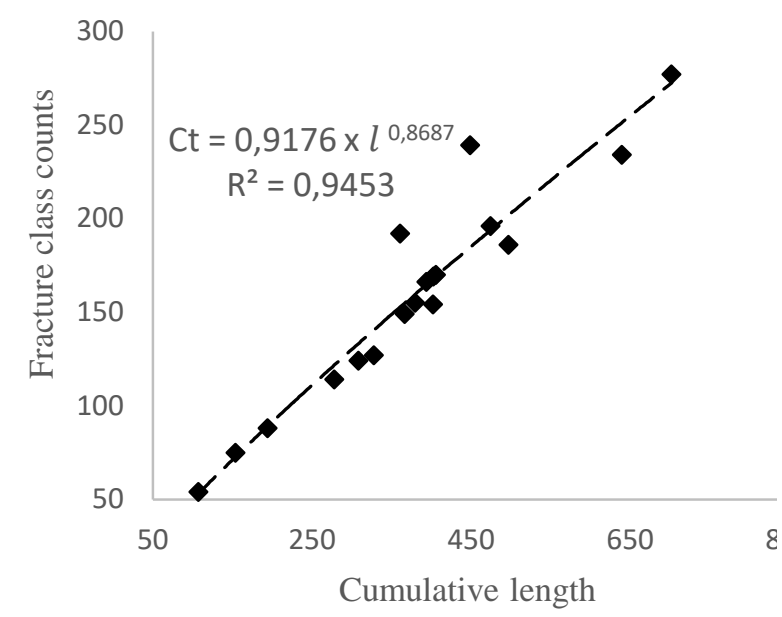

(a)

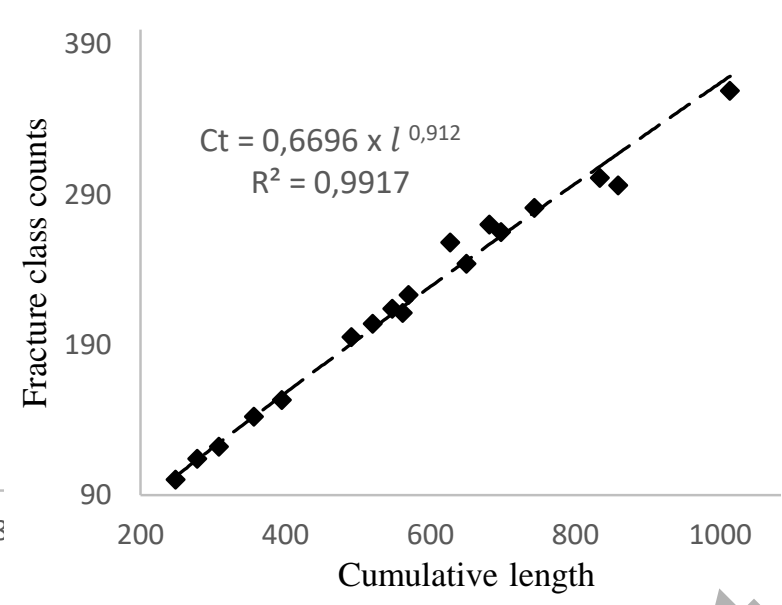

(b)

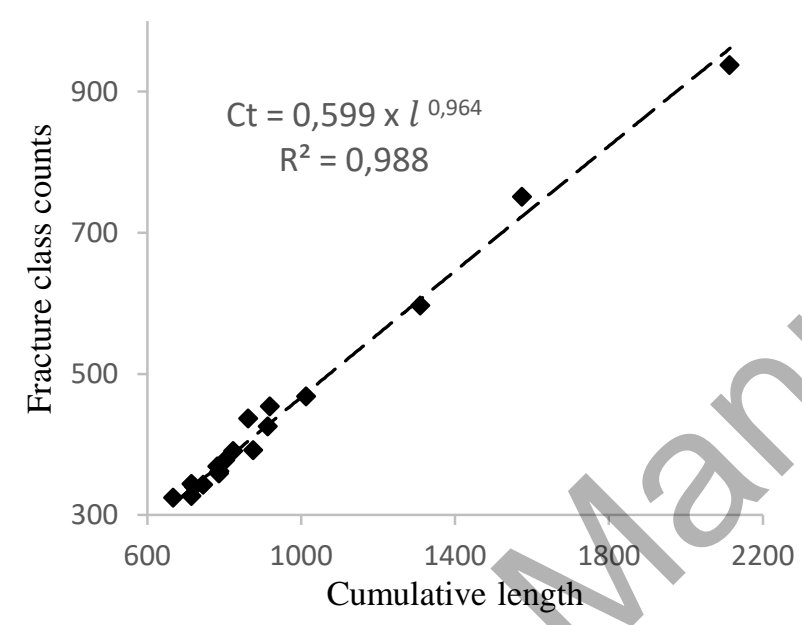

(c)

Figure 2: Cumulative length and class frequency regression of visible (a), Infrared (b) bands and PALSAR (c)

\section{Fracture intersections or cross-points (CP)}

Each cross-point represents the intersection of two or more different orientation fractures. This is relevant for high flow borehole implantation in a basement area since groundwater flow occurs amid those weak areas. The geophysical technics such as vertical electric sounding (VES) can be directly performed at the location of these points. Some main fracture orientations such as the North-South associated to the Kandi Fault in the study area is highly revealed proving the maps accuracy. Furthermore, orientation category statistic of the geological features exhibits the prevailing type of cross-points in each geological formation. For both the visible and PALSAR L dataset, the highest number of cross-points and the second highest of the infrared dataset occur with the North-South (NS) orientation fractures respectively $802 \mathrm{CP}, 6582 \mathrm{CP}$ and $1095 \mathrm{CP}$ (Table 5). This result suggests that for high flow borehole drilling in the basin, the NS orientation fractures are more likely to highlight significantly productive aquifers and should be privileged during geophysical field investigations. The lowest values recorded are $247 \mathrm{CP}$ for the visible, $457 \mathrm{CP}$ for the infrared and 3218 CP for the PALSAR L and each of them occurs with the NWSE orientations. 
Table 5: Cross-points statistics

\begin{tabular}{|c|c|c|c|}
\hline $\begin{array}{c}\text { Cross-points } \\
\text { Intersections }\end{array}$ & Visible & Infrared & Palsar L \\
\hline NS x EW & 454 & 764 & 6582 \\
\hline NS x NESW & 802 & 1095 & 4978 \\
\hline NS x NWSE & 680 & 986 & 4686 \\
\hline EW x NESW & 286 & 538 & 3586 \\
\hline EW x NWSE & 247 & 457 & 3245 \\
\hline NESW x NWSE & 552 & 1175 & 3218 \\
\hline Total & 3021 & 5015 & 26295 \\
\hline
\end{tabular}

Regardless of the type of fracture map, the six types of cross-points are represented in different proportions in the gneiss, granite, mylonites, quartzite and rhyolite (Fig. 3). The most abundant cross-points in the gneiss, mylonites, terrigenous deposits, charnockite and rhyolites alternates among the North-South East-West (NS x EW), North-South North-East South-West (NS x NESW) and North-South North-West South-East (NS x NWSE). This outcome narrows the fracture type to choose during high flow borehole investigations in these geological formations. 


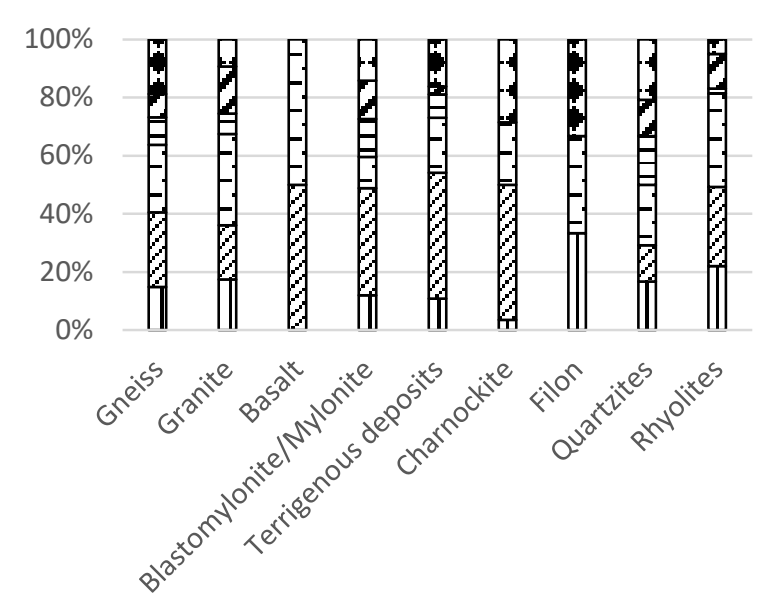

(a)

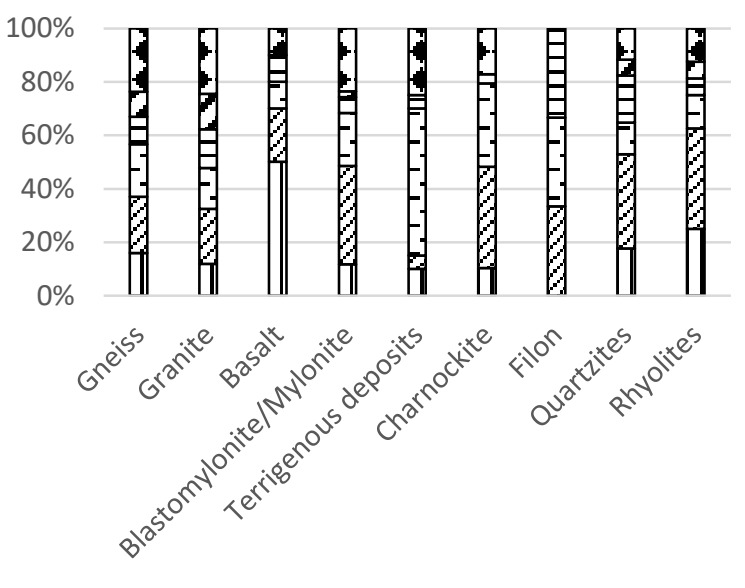

(b)

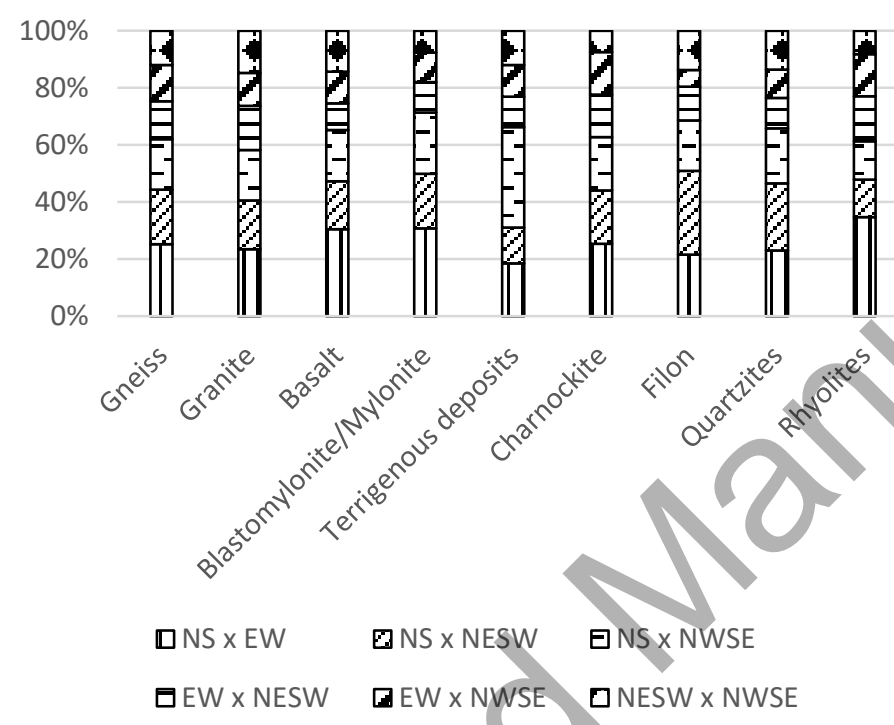

(c)

Figure 3: Cross-points versus geology for visible (a), infrared (b) and PALSAR (c) fracture maps

\section{Orientation and spatial pattern}

Figure 4 depicts the complexity of the fracture network orientations of the three datasets. The highest orientation frequencies occur for the Landsat visible fracture map on N10-N20, N90-N100 and N180. Each interval of orientation counts respectively for $16.4 \%$ with a cumulative length of 1426.7 $\mathrm{km}, 14.6 \%$ with a cumulative length of $1276.8 \mathrm{~km}$ and $8.8 \%$ for a cumulative length of $773.9 \mathrm{~km}$. There is a frequency decrease trend from the North-South orientations (N10-N20 and N180) to the East-West (N90-N100) where a new peak is observed and a secondary orientation N50 with $6.7 \%$ of frequency and a cumulative length of $589.7 \mathrm{~km}$. 


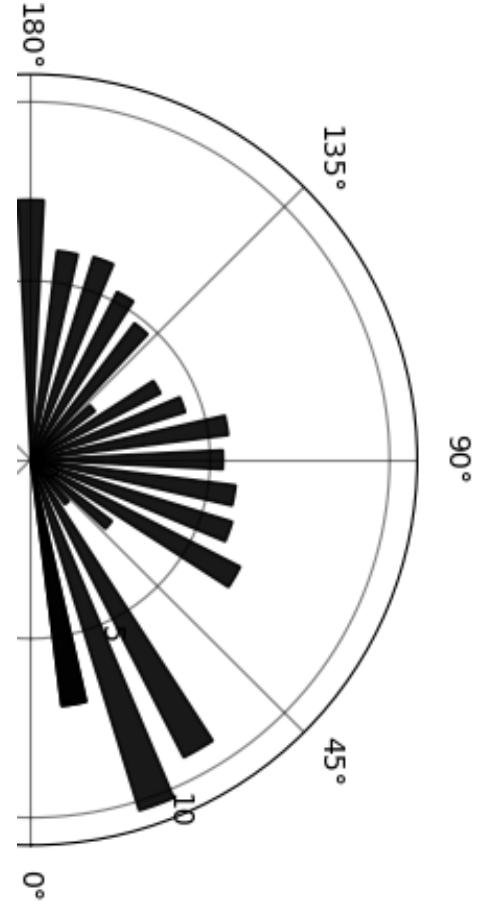

Visible

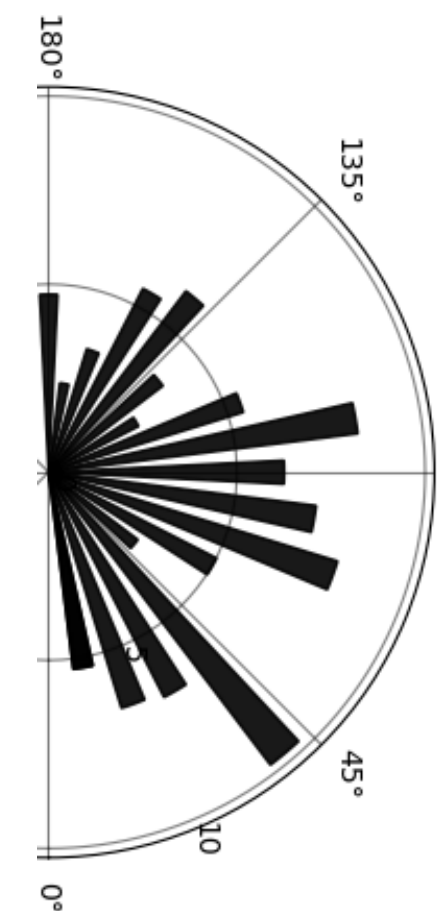

Infrared

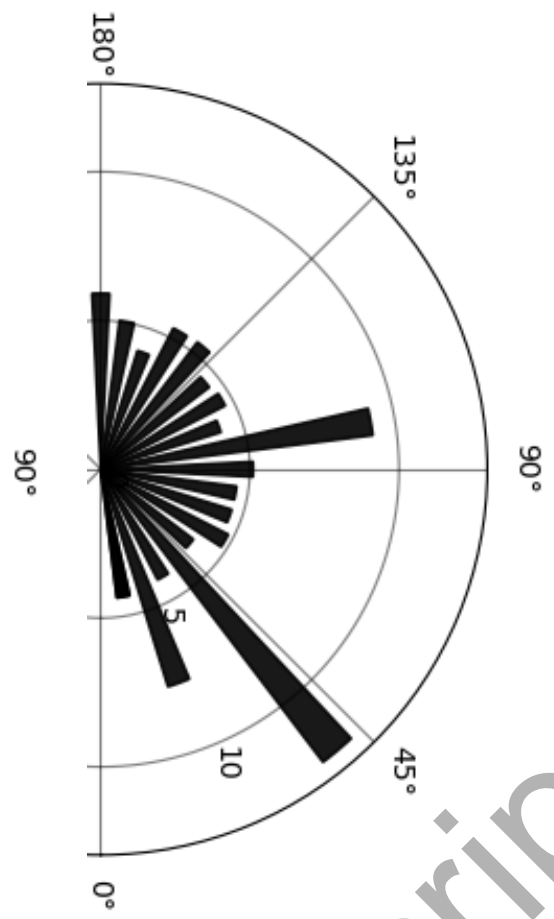

PALSAR

Figure 4: Lineaments length frequency $(\%)$

The infrared fracture map shows main orientations such as N10-N20, N40-N50, N90, N140 and N180 (Fig. 5). The frequency and cumulative length values are respectively $16.2 \%$ for $1928.5 \mathrm{~km}$, $14.8 \%$ for $1755.9 \mathrm{~km}, 6.8 \%$ for $805.6 \mathrm{~km}, 6.4 \%$ for $764 \mathrm{~km}$ and $8.1 \%$ for $967.8 \mathrm{~km}$. Furthermore, the PALSAR L band DEM indicates main orientations like N10-N20, N90-N100 and N170-N180. From this radar dataset the lineaments frequency and cumulative length are respectively $18.2 \%$ for 6024.9 $\mathrm{km}, 11.8 \%$ for $3916.4 \mathrm{~km}$ and $15.7 \%$ for $5216.5 \mathrm{~km}$. Overall, the secondary orientation occurs on N30, N70-N80, N110-N120, and N160, which often connect the main orientations. 




Figure 5: (a) Visible, (b) Infrared and (c) PALSAR DEM extracted fracture maps

The Nearest Neighbour ratio for the visible fracture map is 0.72 with the observed and expected mean distance respectively of $0.64 \mathrm{~km}$ and $0.88 \mathrm{~km}$ (Fig. 6). The infrared fracture map ratio is 0.80 with observed and expected mean distance of $0.66 \mathrm{~km}$ and $0.82 \mathrm{~km}$ and the PALSAR dataset ratio is 
0.83 for observed mean distance of $0.29 \mathrm{~km}$ and expected distance $0.34 \mathrm{~km}$. Given the $z$ scores ($35.9,-26.9$ and -55.2$)$ and $p$ values ( 0 for the three datasets), the lineaments extracted are therefore significantly aggregated.

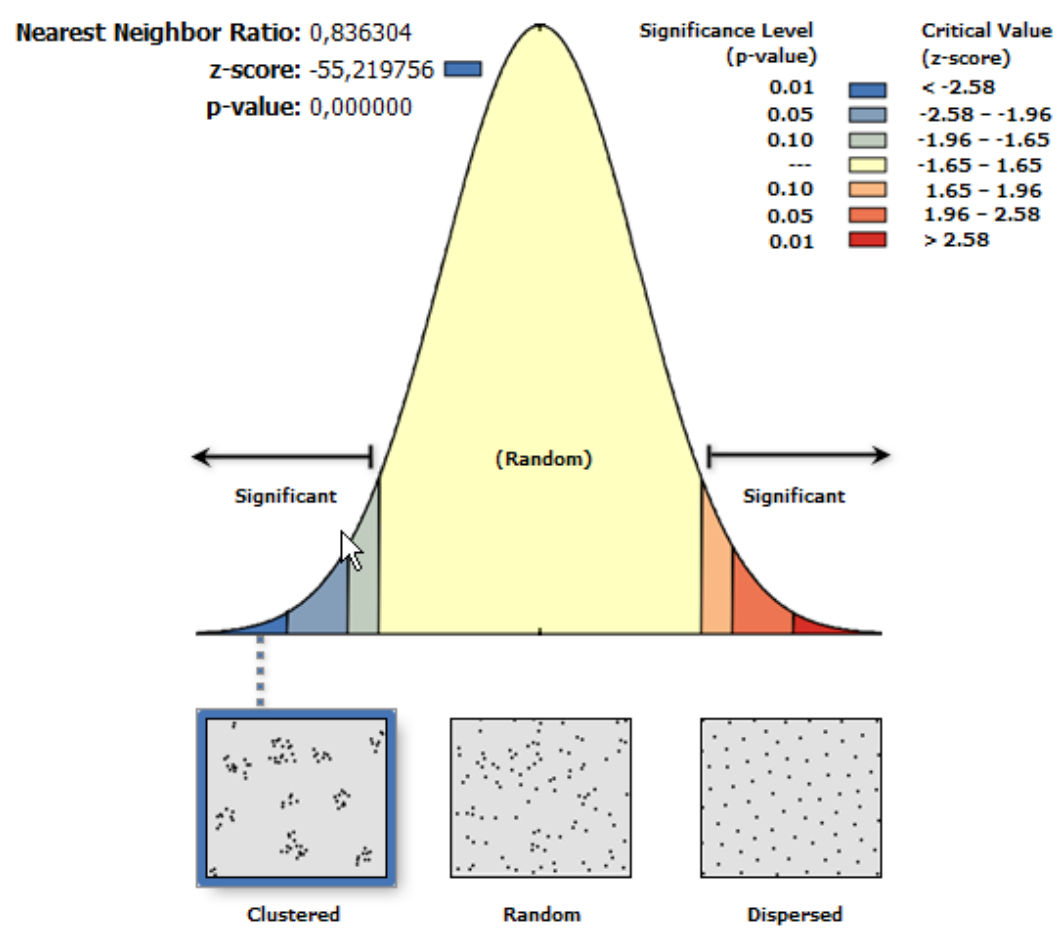

Figure 6: PALSAR L-band lineaments average nearest neighbour summary

The spatial distribution is therefore not random and shows that extracted lineaments are the result of diverse tectonic movements. In average, the highest density is $6.7 \mathrm{~km} / \mathrm{sqkm}$ for the PALSAR fracture map and occurs in the quartzite formations and the lowest average is $5.5 \mathrm{~km} / \mathrm{sqkm}$ recorded in the charnockite (Fig. 7). 


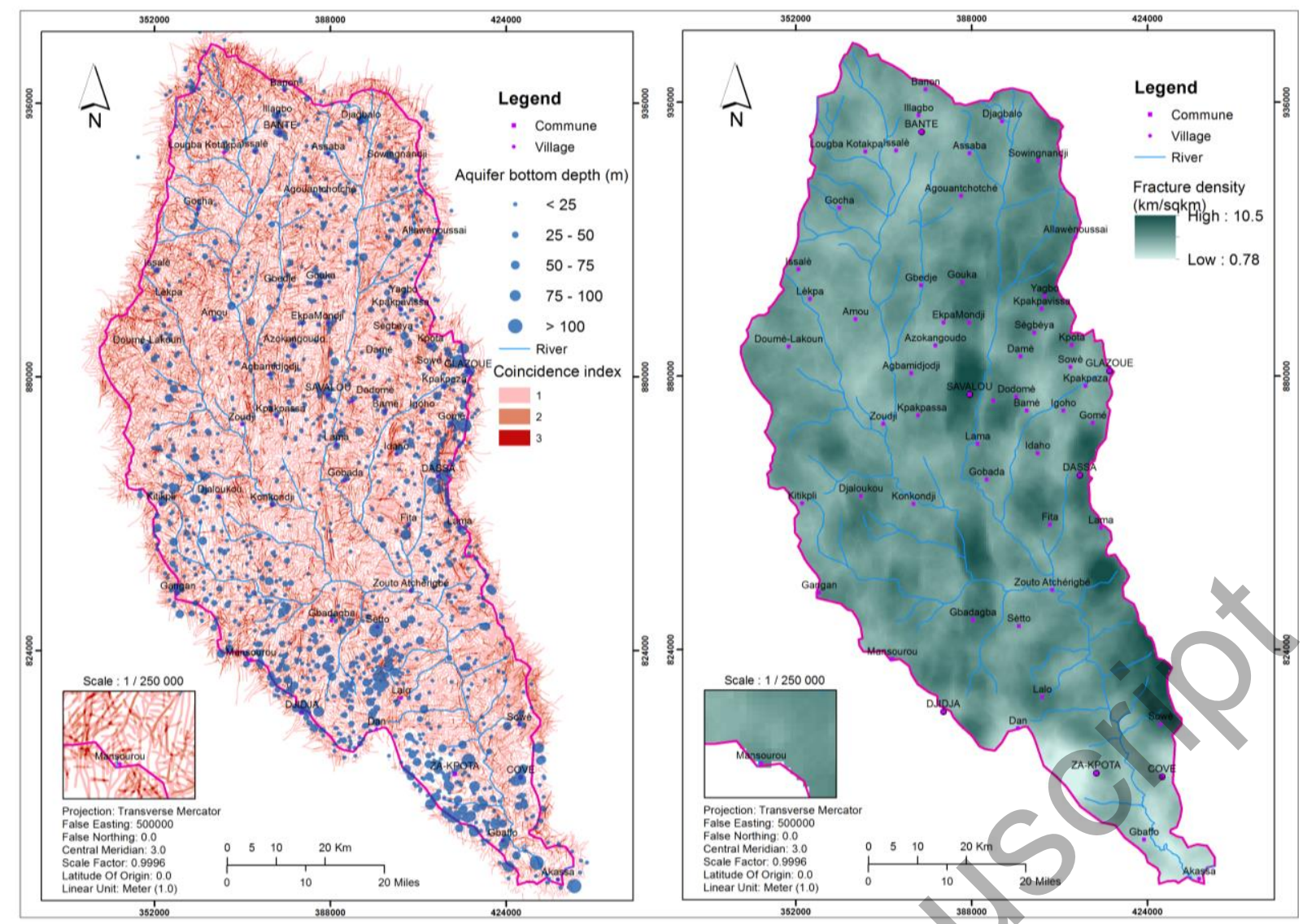

Figure 7: Coincidence (left) and fracture density (rigth) maps

\section{Coincidence map analysis}

After overlapping the layers, the retained areas are 1027.7 sqkm for the visible fracture map, 1377.4 sqkm for the infrared and $1769.1 \mathrm{sqkm}$ for the PALSAR (Table 6). According to the ratios, respectively $0.51,0.68$ and 0.88 , the PALSAR fracture map is the most accurate for weak geological areas identification in the basin (Fig. 7). However, the Landsat visible and infrared fracture maps are interesting too and can be used when Synthetic Aperture Radar (SAR) bands are not available.

Table 6: Fracture maps ranking

\begin{tabular}{|c|c|c|c|c|c|}
\hline Sensors/So & Bands & $\begin{array}{l}\text { Total buffer area at } \\
\text { level } 2 \text { after } \\
\text { overlapping (sqkm) }\end{array}$ & $\begin{array}{l}\text { Retained } \\
\text { buffer area } \\
\text { (sqkm) }\end{array}$ & $\begin{array}{c}\text { Ratio of } \\
\text { retained } \\
\text { area }\end{array}$ & $\begin{array}{l}\text { Image } \\
\text { rank }\end{array}$ \\
\hline OLI - LANDSAT & Visible & \multirow{3}{*}{2016.6} & 1027.7 & 0.51 & 3 \\
\hline TIRS - LANDSAT & Infrared & & 1377.4 & 0.68 & 2 \\
\hline Alos-2 PALSAR & PALSAR & & 1769.1 & 0.88 & 1 \\
\hline
\end{tabular}

Figures 8 and 9 indicate that the NDVI and EVI series are greater in areas mapped as coincidence areas. In these areas, the NDVI mean and standard deviation are respectively $0.61 \pm 0.14$ against $0.57 \pm 0.14$ in non-coincidence areas. The EVI reveals the same picture with mean and standard deviation of $0.38 \pm 0.12$ against $0.36 \pm 0.11$. The mean comparison t-tests of the NDVI and EVI gives 
respectively 2.95 and 2.18 with p-values (0.003 and 0.029) smaller than $5 \%$ threshold. According to Allen (1998), vegetation growth and water availability have reciprocal effects on each other. Even more, water availability is recognized as global driver for vegetation and indirectly affects the local drivers (Yang et al., 2009, Sandi et al., 2020).
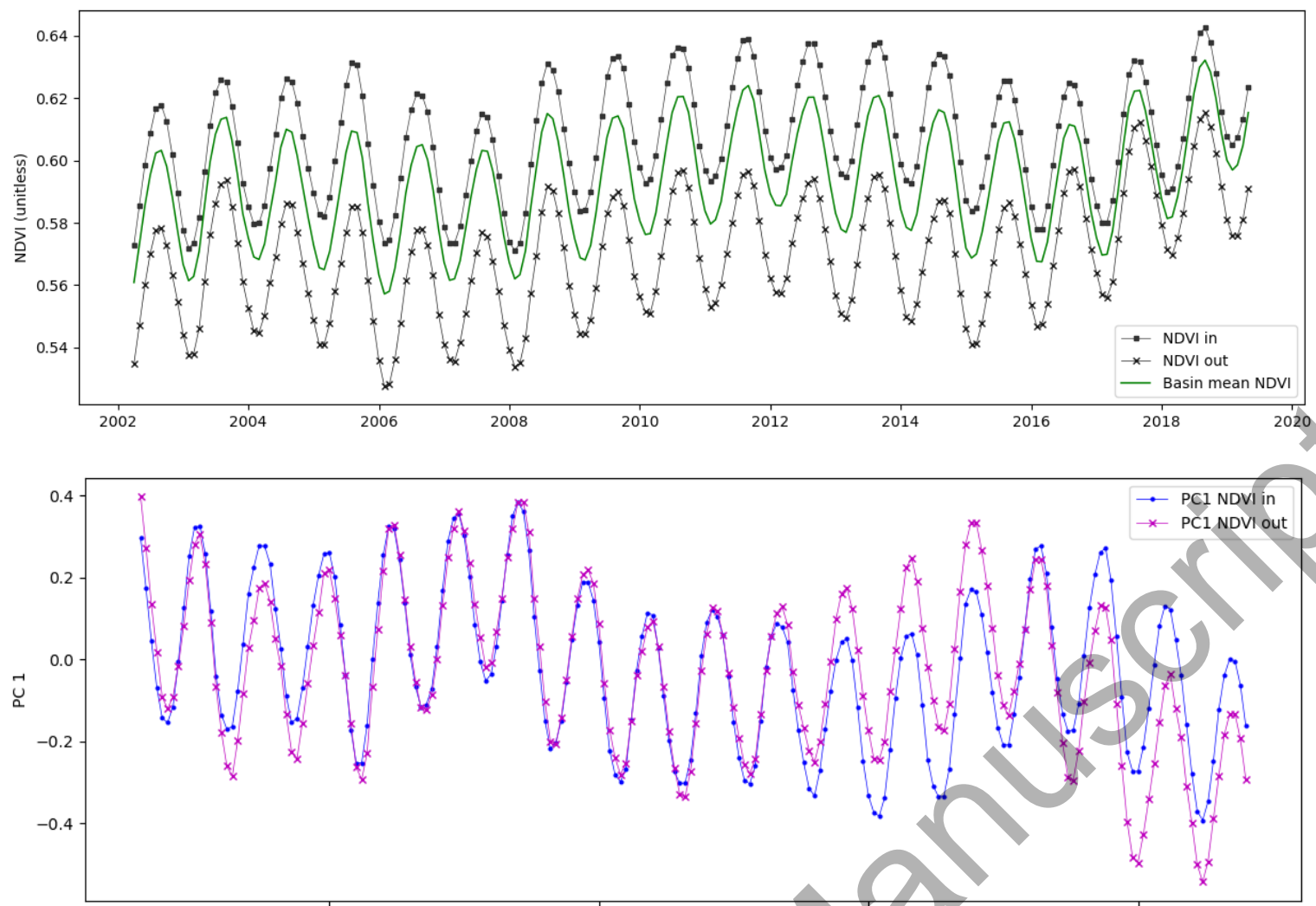

Figure 8: NDVI trends (upper) and first Principal component (lower) in coincidence and noncoincidence areas

Therefore, the evidence of higher vegetation greenness in the lineaments' coincidence areas could be an indicator of water resource availability for a longer time period. The series projection in different dimension through the principal component analysis (PC 1) reveals for both NDVI and EVI four trends from 2002 to 2019. The first uptrend starts from 2002 to 2008, the second downtrend from 2008 to 2013, the third uptrend from 2013 to 2016 and a recent downtrend occurring until 2019. In non-coincidence areas, each PC1 respond early to next unfolding change especially from 2012 to 2019. In contrary, the coincidence areas seem to be more resilient probably due to the higher vegetation greenness. 

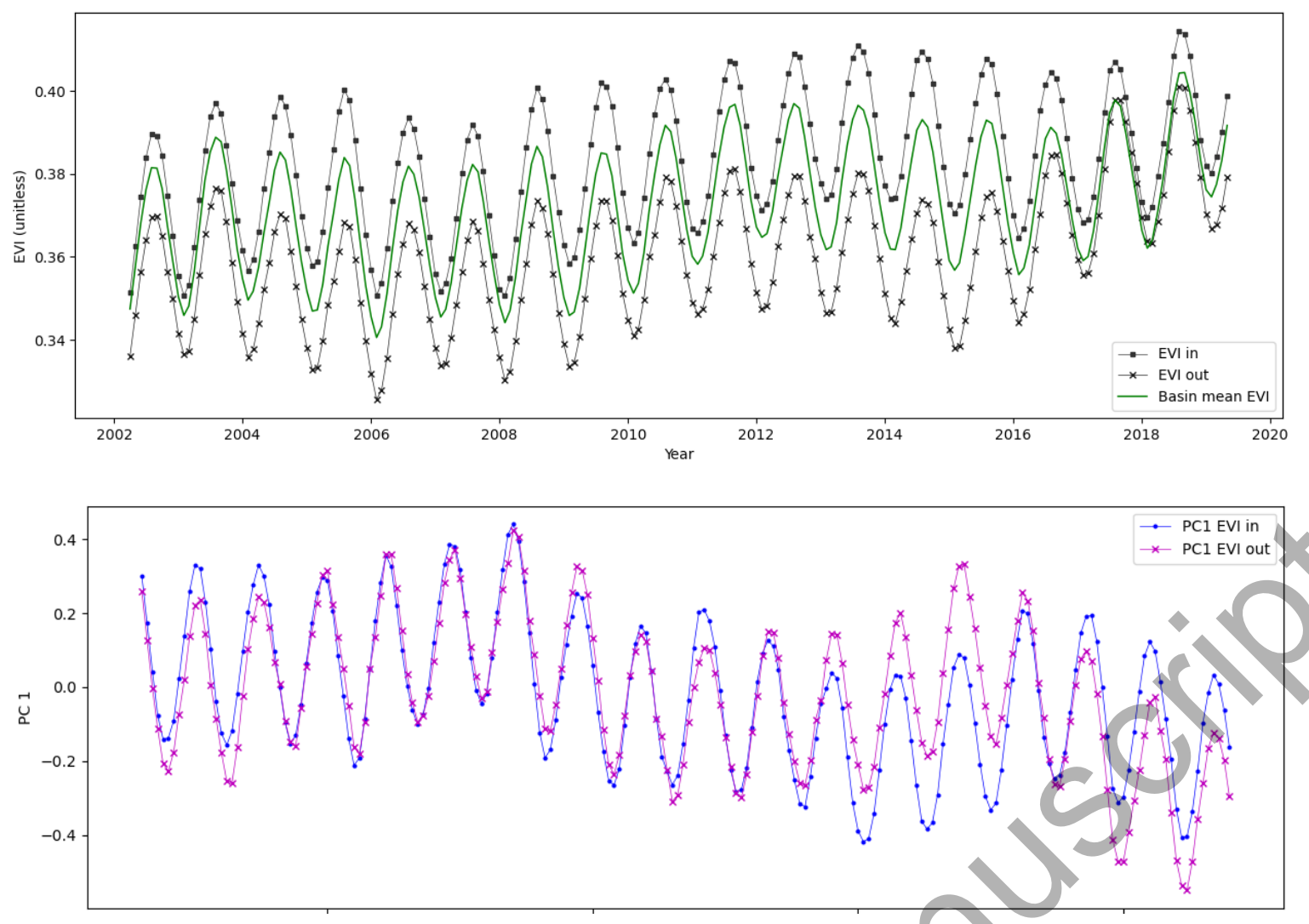

Figure 9: EVI trends (upper) and first Principal component (lower) in coincidence and noncoincidence areas

\section{Fractured aquifers hydrodynamic}

According to the organisation of "Comité Interafricain d'Etude Hydraulique (C.I.E.H) ", the classification shows globally that $37 \%$ of the boreholes has a very low flow (BRGM, 1992). Whatever the geological formation (gneiss, granite, mylonites and terrigenous deposits), more than $50 \%$ of the boreholes has low flow to very low flow rate (Table 7). The percentage of high flow ones varies between $21.5 \%$ in granite and $28.6 \%$ in mylonites.

Table 7: Flow classes versus geological formations

\begin{tabular}{|c|c|c|c|c|c|c|c|c|c|c|}
\hline $\mathbf{Q}\left(\mathbf{m}^{\mathbf{3}} \mathbf{h}\right)$ & \multicolumn{2}{|c|}{ Socle } & \multicolumn{2}{c|}{ Gneiss } & \multicolumn{2}{c|}{ Granite } & \multicolumn{2}{c|}{$\begin{array}{c}\text { Blastomylonit } \\
\text { es and } \\
\text { mylonites }\end{array}$} & $\begin{array}{c}\text { Terrigenous } \\
\text { deposits }\end{array}$ \\
\hline $\mathbf{0 - 1}$ & 680 & 37.0 & 605 & 37.3 & 24 & 30.4 & 25 & 39.7 & 17 & 35.4 \\
\hline $\mathbf{1 - 2 . 5}$ & 464 & 25.3 & 400 & 24.6 & 31 & 39.2 & 15 & 23.8 & 7 & 14.6 \\
\hline $\mathbf{2 . 5}-\mathbf{5}$ & 294 & 16.0 & 265 & 16.3 & 7 & 8.9 & 5 & 7.9 & 13 & 27.1 \\
\hline$>\mathbf{5}$ & 399 & 21.7 & 355 & 21.8 & 17 & 21.5 & 18 & 28.6 & 11 & 22.9 \\
\hline Totals & 1837 & $100 \%$ & 1625 & $100 \%$ & 79 & $100 \%$ & 63 & $100 \%$ & 48 & $100 \%$ \\
\hline
\end{tabular}

According to the standard rules of Drinking Water Supply (Géohydraulique, 1985), the flow of a positive borehole is greater or equal to 0.7 cubic meter per hour (Allé, 2019). The percentage of negative borehole is $21 \%$ in the fractured reservoirs of the granite, $21 \%$ in the gneiss, $27 \%$ in the terrigenous deposits and $23 \%$ in the mylonites of Kandi shear zone (KSZ). As borehole drilling is difficult in the basin, a considerable number of negative boreholes are exploited by the population 
despite the low flow. The boreholes often dry up and are abandoned in favour of poor-quality sources of water like rivers.
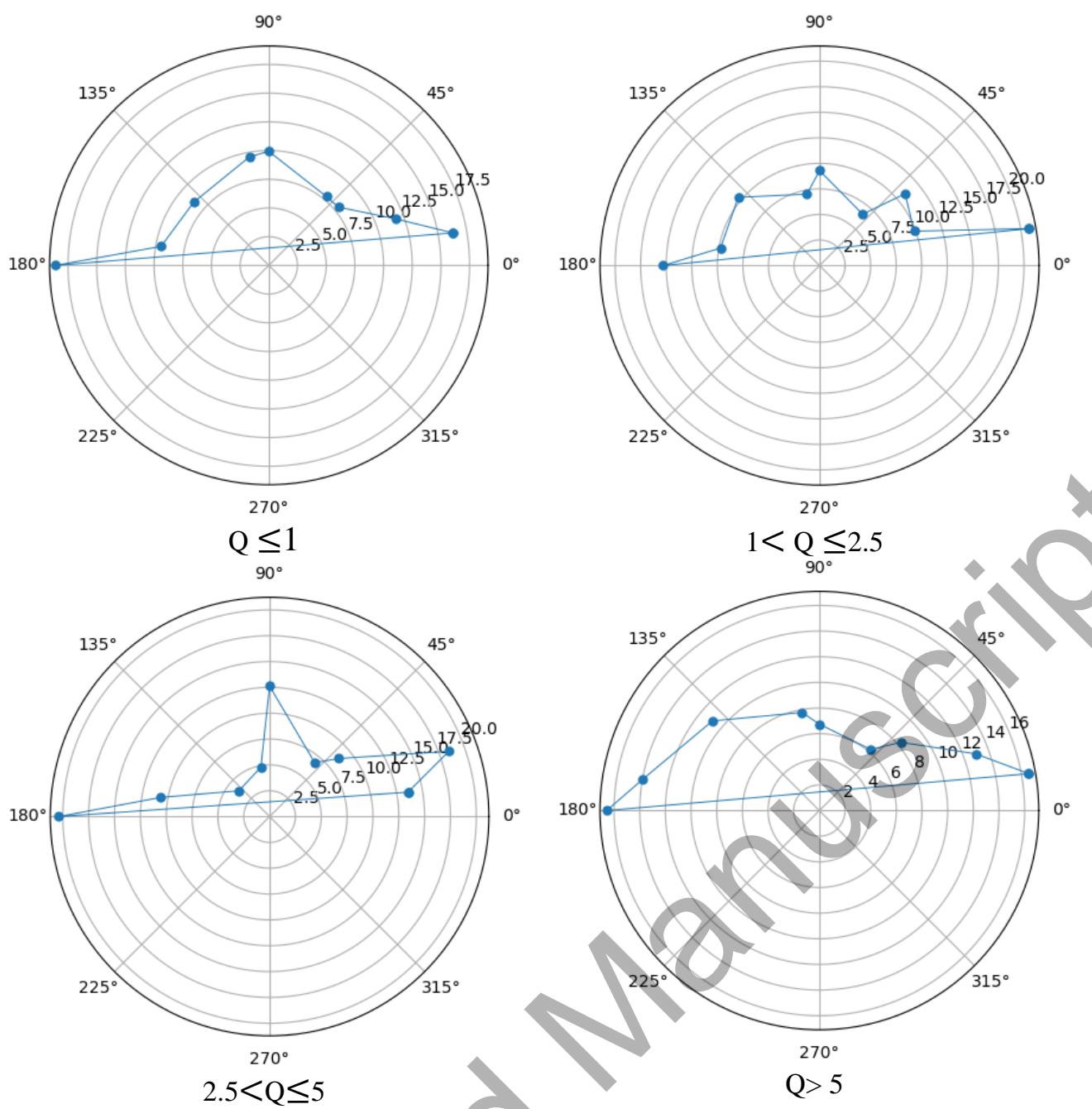

Figure 10: Flow classes versus main fracture orientations

2371 boreholes data are used to evaluate and assess the spatial groundwater flow characteristics based on the major orientations and cross-points. It turns out that more than $50 \%$ of the high flow boreholes (Q>5) are located near the N10, N20 and N180 (North-South) main orientations. These three fracture orientations are confirmed by each fracture map showing how abundant there are and how efficient there could be in drinking water supply for local communities. Further, although the N50, N90 and N100 might be named among the main fracture orientations, the percentage of high flow borehole identified is relatively low (Fig. 10). The N50 orientation is revealed by the infrared fracture map only and the precedent evidence might be a further proof that groundwater investigations in the basin should consider the order of priority in the main orientations when looking for high flow groundwater occurrence areas. In the case of very low flow boreholes $(Q \leq 1)$, the distribution is almost same as in high flow boreholes, but it should be noticed that there is an increase in borehole percentage for the N50, N90 and N100. The type of cross-points located near $38.9 \%$ of high flow and $33.3 \%$ of moderate flow (Table 8) boreholes is North-South North-West South-East (NS x NWSE). The highest percentage of the very low flow boreholes occurs on the North-South East-West (NS x EW), which represents the most abundant cross-points type in the PALSAR fracture map. 
Table 8: Flow classes versus cross-points

\begin{tabular}{|c|c|c|c|c|}
\hline Cross-points & $\mathrm{Q} \leq 1$ & $1<\mathrm{Q} \leq 2.5$ & $2,5<\mathrm{Q} \leq 5$ & $\mathrm{Q}>5$ \\
\hline NS x EW & 26.5 & 15.0 & 8.3 & 16.7 \\
\hline NS x NESW & 21.9 & 10.0 & 25.0 & 11.1 \\
\hline NS x NWSE & 17.9 & 25.0 & 33.3 & 38.9 \\
\hline EW x NESW & 13.2 & 20.0 & 0.0 & 22.2 \\
\hline EW x NWSE & 11.9 & 10.0 & 16.7 & 5.6 \\
\hline NESW x NWSE & 8.6 & 20.0 & 16.7 & 5.6 \\
\hline Total & $100 \%$ & $100 \%$ & $100 \%$ & $100 \%$ \\
\hline
\end{tabular}

\section{Discussion}

The hydrodynamics and aquifers geometry prospection in hard rock areas always require genuine understanding of their geologic tectonic conditions. In this basin, which is predominantly inhabited by people in rural communities, the fractures map accuracy availability appears to be critical for perennial groundwater access. Hence, three sources of dataset (Landsat 8 Visible/Infrared and PALSAR DEM) are processed using Remote Sensing and Geographical Information System technique to come up with as accurate as possible fracture maps for better geophysical and hydrogeological field prospections. Basic statistics of the maps indicate that fracture networks derived from the ALOS- PALSAR DEM has the lowest average length $(1.1 \mathrm{~km})$ and a consistent distribution as the standard deviation of $0.82 \mathrm{~km}$ is less than the visible and infrared values respectively $1.15 \mathrm{~km}$ and $1.4 \mathrm{~km}$. The spatial distribution across the basin depicts a repetitive pattern of longer fractures being broken in smaller one which is one of the reasons why the PALSAR fracture map count is higher. Whatever the visible ( 0.8 to $15.8 \mathrm{~km})$, infrared $(0.3$ to $21.2 \mathrm{~km})$ or PALSAR fracture map $(0.15$ to $11.2 \mathrm{~km})$ is, the interval of length is in consistency with past studies (Tagnon \& al., 2016; Jourda, 2005; Baka, 2012; Lasm \& al., 2014; Koudou \& al., 2013; Koudou \& al., 2014; Oussou \& al., 2019; and Akokponhoué \& al., 2019). For the cumulative length adjustment, the calculated $\chi^{2}$ for the visible and PALSAR fracture maps (61.46 and 37.07) are greater than the theoretical $\chi^{2}$ revealing that there is a significant relationship between the cumulative length and class frequency. Although, the infrared fracture map calculated $\chi^{2}$ is less than the theoretical $\chi^{2}$, the power law adjustment for the three fracture maps gives in each case strong and positive correlation coefficients (visible 0.94, infrared 0.99 and PALSAR 0.98). A significant groundwater flow in a section of the basin therefore depends on the fracture length and the spatial distribution connectivity. The fractures length distribution is generally adjusted to the power law and this study corroborates works such as Bonnet \& al., 2001, De Dreuzy \& al., 2000, Tagnon \& al., 2016). According to Bonnet \& al., 2001 and Darcel \& al., 2003 cited in Tagnon \& al., 2016, the exponent characteristic $\alpha$ of the power law and fracture density control the connectivity of the fracture media. The exponent characteristic obtained in this work are respectively $0.86,0.91$ and 0.96 and they appear to be outside the recommended interval $(2 \leq \alpha \leq 3)$ in the literature.

The fracture cross-points (CP) distribution and density in a specific area can be obviously revealing of the fractured aquifer connectivity and underground water flow. Whatever the fracture map, the highest percentage of cross-points occurs with the North-South (NS) orientation fractures respectively $64.1,56.7$ and $61.7 \%$. Therefore, the NS orientation fractures should purposely be considered as there could highlight significantly productive aquifers. In the opposite side, the minimum number of cross-points are $247 \mathrm{CP}$ for the visible, $457 \mathrm{CP}$ for the infrared and $3218 \mathrm{CP}$ for the PALSAR. In this case, it turns out that the North-West South-East (NWSE) orientation fractures are the dominant. The geological formations such as gneiss, granite, mylonites, quartzite and rhyolite registered a significant percentage of the six cross-points types. The North-South East-West (NS x EW), North-South North-East South-West (NS x NESW) and North-South North-West South-East 
(NS x NWSE) represent the general cross-points spectrum in the gneiss, mylonites, terrigenous deposits, charnockite and rhyolites. Furthermore, for the PALSAR fracture map, the cross-points spatial densities are $8 \mathrm{CP} / \mathrm{sqkm}$ in the rhyolites, $7 \mathrm{CP} / \mathrm{sqkm}$ in the basalt, $4 \mathrm{CP} / \mathrm{sqkm}$ in the quartzite, $3 \mathrm{CP} / \mathrm{sqkm}$ in the charnockite, $4 \mathrm{CP} / \mathrm{sqkm}$ in the granite, $2 \mathrm{CP} / \mathrm{sqkm}$ in the mylonites, $3 \mathrm{CP} / \mathrm{sqkm}$ in the gneiss and the terrigenous deposits.

Fracture rose diagrams of the maps reveal dominant orientation such as N10-N20, N90-N100 and N180 in the basin. The orientations frequency and cumulative lengths are in the case of the visible fracture map, respectively, $16.4 \%$ for $1426.7 \mathrm{~km}, 14.6 \%$ for $1276.8 \mathrm{~km}$ and $8.8 \%$ for 773.9 $\mathrm{km}$, in the case of the infrared fracture map respectively $16.2 \%$ for $1928.5 \mathrm{~km}, 6.8 \%$ for $805.6 \mathrm{~km}$ and $8.1 \%$ for $967.8 \mathrm{~km}$ and finally in the case of the PALSAR fracture map respectively $18.2 \%$ for $6024.9 \mathrm{~km}, 11.8 \%$ for $3916.4 \mathrm{~km}$ and $15.7 \%$ for $5216.5 \mathrm{~km}$. The N10-N20 and N180 represent a significant orientation in the central area of Benin republic especially the Kandi Shear Zone (KSZ) related to the pan-African orogenic cycle as recognized by many authors (Breda, 1985, Adissin Glodji, 2012 and Alhassane \& al., 2018). Further, it characterizes the crystallophyllian orientation of schistose green rocks, gneisses (NS to NNE-SSW, NNW-SSE), migmatites, and the extension of granite and spilite-keratophyre massifs (Boukari, 1982, Breda, 1989, Akokponhoué \& al., 2019 and Oussou \& al., 2019). The secondary orientation N60, includes the NE-SW steering faults that affected the series of alkaline microgranites (Pougnet, 1957 cited in Boukari, 1982), the general orientation of the migmatites (N65) and the emplacement of the large batholiths of the porphyroid granite of Dassa-Zoumé. An ESE-NWN aplite injections close to the secondary directions N110N120 have been confirmed in 'Lhoto' valley fractures. A fracture map spacing analysis using the Nearest Neighbour technic is a simple way to find out whether the fracture network is aggregated or randomly distributed. The ratios of the three fracture maps (respectively $0.72,0.80$ and 0.83 ) and $\mathrm{z}$ scores $(-35.9,-26.9$ and -55.2$)$ show that there is a significant spatial aggregation meaning that a tectonic geological movement have affected the formations. Based on the spatial density of the PALSAR fracture map, the Quartzite is more affected with a density of $6.7 \mathrm{~km} / \mathrm{sqkm}$ and the charnockite is less affected recording $5.5 \mathrm{~km} / \mathrm{sqkm}$.

The coincidence map is a tool for better and more precise fracture identification. Therefore, the retained areas after buffer calculation and overlapping are $1027.7 \mathrm{sqkm}, 1377.4 \mathrm{sqkm}$ and 1769.1 sqkm respectively for the visible, infrared and PALSAR. The PALSAR fracture map has the highest coincidence ratio of 0.88 which shows that the image gives a better accuracy compared to the visible and the infrared. The works of Bruning \& al., (2009) and Alonso-contes (2011) carried out respectively in a volcanic terrain in Nicaragua and karst terrain in Puerto Rico corroborates this outcome. The radar dataset (ALOS PALSAR, Radarsat-1, Sentinel-1...) and derived products (DEM, NDPI...) are given priority over optical images (Landsat-8, Sentinel-2, etc.) for accurate fracture identification. Although, this is the default trend, visible and infrared fracture maps can be interesting too when radar images are not available. The lineaments' coincidence areas evaluation using the NDVI and EVI series has proved their capacity to bear higher seasonal vegetation greenness compared to the non-coincidence areas which tend to react quickly to future unfolding changes. The NDVI and EVI mean comparison using t-tests have proved that there is significant difference as the p-values are less than the 5\% threshold. The first principal component graphs depict two uptrends (2002-2008 and 2013-2016) and two downtrends (2008-2013 and 2016-2019) which show the climate temporal dynamic across the basin from vegetation greenness perspective. The temporal trend is to explain how water presence clues (ex. vegetation greenness, soil moisture, aquifers' discharge areas...) have changed comparing the "coincidence areas" to "non-coincidence areas". Figures 8 and 9 revealed that the "coincidence areas" have higher vegetation greenness (vegetation indexes) and are more resilient in dry season and to drought events (Principal Component Analysis).

Regardless of the geological context, at least $50 \%$ of the boreholes has a low flow to very low flow rate $(\mathrm{Q} \leq 2.5)$. Negative boreholes' percentage can reach overall 40\% (Allé, 2019) in the country basement area but there is an obvious change from one type of geology to another one (terrigenous 
deposits $27 \%$, mylonites of Kandi shear zone $23 \%$, granite $21 \%$ and gneiss $21 \%$ ). As aquifer's geometry and hydrodynamic appear to be very complex in the basin, borehole characteristics flip randomly. Comparing with past studies (Allé, 2019 and Oussou, 2019; Boukari, 1982), the relatively low productivity of the fractured aquifers in the study area appear to be consistent. Although the low flow, boreholes are equipped for communities drinking water supply. In mylonites, high flow rate boreholes $(\mathrm{Q}>5)$ reaches a high percentage of $28.6 \%$ and a lowest value of $21.5 \%$ is recorded in the granite. The hydrodynamic characteristics of a fractured aquifers after all depend on how intense the fracture density is both in 2D and 3D. From this perspective, the fracture maps reveal the surface 2D geometry and the existing borehole data offer valuable underground characteristics.

From borehole discharge versus orientation and cross-points (CP) perspective, near the N10, $\mathrm{N} 20$ and N180 (North-South) main orientations are located more than 50\% of high flow boreholes. The presence of these orientations is key to find more easily productive aquifers in the basin. However, because of their abundance and the fact that the boreholes characteristics (discharge, depth, geographical position) depend mainly on communities drinking water needs, a non-negligible percentage of low flow boreholes is noticed. The N50, N90 and N100 are abundant too but located often near less productive boreholes. This evidence proves the order of priority which continues until the secondary classes of orientations. Furthermore, $38.9 \%$ of high flow and $33.3 \%$ of moderate flow boreholes are located near $(200 \mathrm{~m})$ the cross-points type North-South North-West South-East (NS x NWSE). Cross-points (CP) occurring with the NS orientations are more likely to reveal productive fractured aquifers. Two conditions prevailed in the basin. First, the borehole can be deep (around 80 $\mathrm{m}$ ) and the flow rate does not increase with the depth (limited productivity): in this case, it usually ends in a dry or a weakly productive fracture. The second case is when the borehole is less deep (around $30 \mathrm{~m}$ ) and productive: this second case, generally occurs when the precedent described conditions are met favouring safe drinking water supply.

\section{Conclusions}

Assessing the status of aquifers is crucial to supporting reasonable management of groundwater resources for domestic applications such as drinking. Understanding of aquifers' geometry in relation to drinking water access in basement environments through satellite images and groundwater hydrodynamic is therefore crucial. The Zou basin has a complex fracture network controlled by main orientations N10-N20, N90-N100 and N180, which define aquifers' geometry and secondary orientations N30, N70-N80, N110-N120, and N160. In this study, fracture maps derived products and statistics are made available for more efficient installations of boreholes. The cross-points, cumulative length and spatial density statistics depict the basin aquifers' 2D spatial pattern, which apprehension is critically required. Coincidence map obtained from the three fracture maps indicate the order of priority (ALOS-PALSAR DEM, Landsat Infrared and Landsat visible) when it comes to choosing the right satellite image. Existing borehole flow data combined with geology, main orientations and cross-points extend the analysis to better understanding of the prevailing groundwater flow system. Therefore, synergy between remote sensing communities and hydrogeologists will facilitate groundwater flow assessment, and the combined use of numerical models with remote sensing techniques and field data provides a platform to improve such understanding. Increased groundwater demand is often caused by a rise in human population and demands from industry and agriculture. Groundwater modelling that integrates remote sensing information and numerical models could be useful in predicting surface deformations and other known impacts associated with extensive groundwater use. To achieve the Sustainable Development Goals (SDG) and reach a long-term reliable water supply in the basin, groundwater modelling of the fractured aquifers should be undertaken at local scale based on the above results and water pumping simulation performed for better future projection.

\section{Acknowledgments}


The authors are grateful to NASA and NOAA through ASF DAAC and EROS centers for all the satellite data and the National Department of Water Resources (DG-Eau) for borehole data used in this study. We also thank the reviewers for their valuable suggestions, which led to significant improvement of this manuscript.

\section{References}

Ackermann RV, Schlische RW, Withjack M. 2001. The geometric and statistical evolution of normal fault systems: an experimental study of the effects of mechanical layer thickness on scaling laws. Journal of Structural Geology, 23, 1803-1819.

Adissin Glodji CL. 2012. La zone de cisaillement de Kandi et le magmatisme associé dans la région de Savalou-Dassa (Bénin): étude structurale, pétrologique et géochronologique. Doctorat unique des Universités Jean Monnet Saint-Etienne et d'Abomey-Calavi; France-Bénin; p260

Afouda F. 1990. L'eau et les cultures dans le Bénin central et septentrional: étude de la variabilité des bilans de l'eau dans leurs relations avec le milieu rural de la savane africaine. Thèse de doctorat, Université Paris IV Sorbonne, 448 p.

Alidou S, Bard JP, Julien M. 1975. Conglomérats métamorphiques d'affinité tillique dans le socle dahoméen. $3^{e}$ Réun. Ann. Sci. Terre, Mont-pellier, Fr., p6.

Allen R, Pereira L, Raes D, and Smith M. 1998. Crop evapotranspiration guidelines for computing crop water requirements. FAO Irrig. Drain. Pap. 56, Food and Agric. Organ. of the U. N., Rome.

Akokponhoué YN, Yalo N, Akokponhoué HB, Youan Ta M,Agbahoungba G. 2019. Apport de la Télédétection et de la Géophysique dans la cartographie des fractures hydrauliquement actives en zone de socle au Centre-Ouest du Bénin. European Scientific Journal, Vol.15, No.27 ISSN: 1857 - 7881. Doi:10.19044/esj.2019.v15n27p426

Alhassane I, Maman Sani AB, Issoufou S, Bachir SM, Boureima O. 2018. Apport des images ETM+ et du Modèle Numérique de Terrain (MNT) à la Cartographie des fractures en région montagneuse: Secteur de Timia (Massif de l'Aïr, Nord du Niger). European Scientific Journal, edition Vol.14, No.9 ISSN: 1857 - 7881.Doi: 10.19044/esj.2018.v14n9p103

Allé IC, 2019. Évaluation de l'implantation géophysique des forages d'eau en zone de socle en milieu tropical (Bénin, Afrique de l'Ouest): apport de la tomographie de résistivité électrique pour la caractérisation de la cible hydrogéologique. Thèse 3ème cycle, Université d'AbomeyCalavi, Bénin, pp.

Alonso-Contes CA. 2011. Lineament mapping for groundwater exploration using remotely sensed imagery in a karst terrain: Rio Tanama and Rio de Arecibo basins in the northern karst of Puerto Rico. Master's Thesis, Michigan Technological University. http://digitalcommons.mtu.edu/etds/309

ASF DAAC. 2015. ALOS PALSAR Radiometric Terrain Corrected low resolution; Includes Material @ JAXA/METI 2007. Accessed through ASF DAAC 25 October 2016. doi:10.5067/JBYK3J6HFSVF

Assatse WT, Nouck PN, Tabod CT, Akame JM, Biringanine GN. 2016. Hydrogeological activity of lineaments in Yaounde Cameroon region using remote sensing and GIS techniques. The Egyptian Journal of Remote Sensing and Space Sciences. p.12. http://dx.doi.org/10.1016/j.ejrs.2015.12.006 
Awoyé R. 2007. Modélisation du bilan hydrologique du bassin versant du Klou: contribution à la gestion durable des ressources en eau dans le Zou. Thèse d'ingénieur FSA/UAC, Bénin, p. 100.

Aydal D, Arda1 E \& Dumanlilar Ö. 2007. Application of the Crosta technique for alteration mapping of granitoidic rocks using ETM+ data: case study from eastern Tauride belt (SE Turkey), International Journal of Remote Sensing, 28:17, 3895-3913, https://doi.org/10.1080/01431160601105926.

Baka D. 2012. Géométrie, hydrodynamisme et modélisation des réservoirs fracturés du socle protérozoïque de la région d'Oumé (Centre-Ouest de la Cote d'Ivoire). Thèse Unique, Univ. F.H. Boigny, Abidjan, Côte d'Ivoire, 249 p

Becker MW. 2006. Potential for satellite remote sensing of groundwater. Ground Water 2006: 44(2): 306-18.

Biémi J. 1992. Contribution à l'étude géologique, hydrogéologique et par Télédétection des bassins versants subsahéliens du socle précambrien d'Afrique de l'Ouest Hydrostructurale, hydrodynamique, hydrochimie et isotopie des aquifères discontinus des sillons et aires granitiques de la Haute Marahoué (Côte d'Ivoire). Thèse d'Etat Université Nationale de Côte d'Ivoire.

Boko M. 1988. Climat et communautés rurales au Bénin, rythmes climatiques et rythmes de développement. Thèse de doctorat d'Etat. Université de Bourgogne, Dijon, 605p.

Bokonon-Ganta EB. 1987. Les climats de la région du Golfe du Bénin. (Afrique Occidentale). Thèse de doctorat du 3ème cycle. Paris IV, Sorbonne. p $248+$ Annexes.

Bonhomme M. 1962. Contribution à l'étude géochronologique de la plate-forme de l'Ouest Africain. Ann. Fac. Sci. Univ. Clermont, v. 5, 60 p.

Bonnet E, Bour O, Odling NE, Davy P, Main IG, Cowie PA, Berkowitz B. 2001. Scaling of fracture systems in geological media. Review of Geophysics, 39, 347-383.

Boukari M. 1998. Fonctionnement du système aquifère exploité pour l'Approvisionnement en Eau de la ville de Cotonou sur le littoral Béninois. Impacte du développement urbain sur la qualité des ressources. Thèse 3ème cycle, Université cheik Anta Diop, Dakar, Sénégal, p256.

Boukari M. 1982. Contribution à l'étude hydrogéologique des régions de socle de l'Afrique intertropicale: l'hydrogéologie de la région de DASSA-ZOUME (Bénin). Thèse 3ème cycle; Université Cheik Anta Diop Dakar; Sénégal; p140

Boukari M. 2002. Réactualisation des connaissances hydrogéologiques relatives au bassin sédimentaire côtier du Bénin. p3-134

Bourguet L, Camerlo J, Fahy JC, Vailleux Y. 1980-1981. Méthodologie de la recherche hydrogéologique en zone de socle cristallin. Bull. B.R.G.M. Sér. II, Sect. III, nº . 4, pp. 311-324.

Boussari W, Rollet M. 1974. Découverte d'un bassin volcano-sédimentaire dans la région CentreOuest du Dahomey. Comptes Rendus Académie des Sciences, Paris, 279, 29-32.

Breda. 1985. Etude de la cartographie géologique et prospection minière de reconnaissance au Sud du 9ème parallèle. Première phase, 111p. 
Breda. 1989. Notice explicative de la carte géologique à 1/200000. Feuilles Pira-Savè, AbomeyZagnanado, Lokossa-Porto-Novo. 77p.

BRGM. 1992. Document - Guide pour l'implantation et la mise en exploitation des forages à gros débit en zone de socle cristallin. Rapport C.I.E.H, Octobre 1992. p88 + Annexes.

Bruning JN, Gierke JS, Maclean AL. 2009. Digital processing and data compilation approach for using remotely sensed imagery to identify geological lineaments in hard-rock terrains: an application for groundwater explorations in Nicaragua. ASPRS 2009 Annual Conference Baltimore, Maryland, March 9-13, 2009

Canny JA. 1986. Computational approach to edge detection. IEEE Trans. Pattern Anal. Mach. Intell. 1986, PAMI-8, 679-698.

Das D. 1990. Satellite remote sensing in subsurface water targeting. In: Proceeding ACSM-ASPRS Annual Convention, pp. 99-103.

Darcel C, Bour O, Davy P, De Dreuzy JR. 2003. Connectivity properties of two dimensional fracture networks with stochastic fractal correlation. Water Resources Research, 39, 1272-1285

D’Almeida GAF, Yessoufou S, Chala D, Obossou L. 2015. Caractéristiques pétrographiques et structurales des calcaires du département du Zou, sud du Bénin. Afrique Science 11(6) (2015) 139 - 157. ISSN 1813-548X. p19

De Dreuzy, J.R., Davy, P., Bour, O., 2000. Percolation threshold of 3D random ellipses with xidelyscattered distributions of eccentricity and size. Physical Review E, 62, 5948-5952.

Deriche R. 1987. Using cannys criteria to derive a recursively implemented optimal edge detector. Int. J. Comput. Vision 1987, 1, 167-187.

Dewandel B, Lachassagne P, Wyns R, Marechal JC, Krishnamurthy NS. 2006. A generalized hydrogeological conceptual model of granite aquifers controlled by single or multiphase weathering. Journal of Hydrology, 330,260-284, doi:10.1016/j.jhydrol.2006.03.026

Didan K. 2015. MOD13Q1 MODIS/Terra Vegetation Indices 16-Day L3 Global 250m SIN Grid V006. NASA EOSDIS Land Processes DAAC. Accessed 2020-08-27 from https://doi.org/10.5067/MODIS/MOD13Q1.006. Accessed August 27, 2020.

El-Sawy K, Atef MI, El-Bastawesy MA, El-Saud WA. 2016. Automated, manual lineaments extraction and geospatial analysis for Cairo-Suez district (Northeastern Cairo-Egypt), using remote sensing and GIS. IJISET, Vol. 3 Issue 5, ISSN 2348 - 7968.

Ferreira V, Montecino H, Ndehedehe C, Heck B, Gong Z, Westerhaus M, de Freitas S. 2018. Spacebased observations of crustal deflections for drought characterization in Brazil. Sci. Total Environ. 644, 256-273. https://doi.org/10.1016/j.scitotenv

Houssou CS. 1998. Les bioclimats humains de l'Atacora (Nord-Ouest du Bénin) et leurs implications socio-économiques. Thèse pour l'obtention du grade de Docteur de l'Université de Bourgogne

Jourda JPR. 2005. Méthodologie d'application des techniques de télédétection et des systèmes d'information géographique à l'étude des aquifères fissurés d'Afrique de l'Ouest. Concept de 
l'hydrotechnique spatiale: cas des zones tests de la Côte d'Ivoire. Thèse de Doctorat d'Etat ès Sciences Naturelles. Univ. Cocody (Abidjan, Côte d'Ivoire). 403 p.

Geohydraulique, (1985). 'Notice descriptive de la carte Hydrogéologique du Bassin Sédimentaire Côtier du Bénin à l'échelle 1/200 000è “". Géohydraulique 1985.

Guiraud R, Alidou S. 1981. La faille de Kandi (Bénin), témoin du rejeu fini-crétacé d'un accident majeur à l'échelle de la plaque africaine. C.R. Acad. Sci., Paris, t. 293, p.7779-7782.

Jolliffe I.T., 2002. Principal component analysis. Springer Series in Statistics, second edition. Springer, New York.

Kamagate B, Gone DL, Doumouya I, Ouattara I, Ouedraogo M, Bamba A, Savane I. 2011. Relation nappe-rivière dans le bassin versant du Bandama en milieu de socle fissuré en Côte d'Ivoire: approche couplée hydrochimie - télédétection. Int. J. Biol. Chem. Sci. 5(1): 206-216, February 2011, ISSN 1991-8631.

Kouamé KF, Lasm T, Saley MB, Tonyé E, Bernier M, Wade S. 2009. Extraction linémentaires par morphologie mathématique sur une image RSO de RADARSAT-1: application au socle Archéen de la Côte d'Ivoire. Journées d'Animation Scientifique (JAS09) de l'AUF, Alger Novembre 2009.

Koudou A, Lasm T, Kouame KF, Youan Ta M, Assoma TV, Biémi J. 2013. Contribution des images aster à la connaissance des aquifères fracturés de la région de Duékoué (Ouest de la Cote d'Ivoire). Photo-Interprétation, European Journal of Applied Remote Sensing, n²012/4, 48-66.

Koudou A, Assoma TV, Adiaffi B, Youan Ta M, Kouamé KF, Lasm T. 2014. Analyses statistique et géostatistique de la fracturation extraite de l'imagerie ASAR ENVISAT du Sud-Est de la Côte d'Ivoire. Larhyss Journal, (20), 147-166.

Lasm T, Kouamé KF, Soro N, Jourda JPR, Biémi J. 2004. Analyse géostatistique de la fracturation extraite de l'imagerie spatiale aeroportée et satellitaire. Application à la région de Man-Danané (Ouest de la Côte d'Ivoire). Revue Ivoirienne des Sciences et Technologiques, 5, 135-154

Lachassagne P, Wyns R, Dewandel B. 2011. The fracture permeability of Hard Rock Aquifers is due neither to tectonics, nor to unloading, but to weathering processes. Terra Nova, 23. 145-161

Magesh NS, Chandrasekar N, Soundranayagam JP. 2012. Delineation of groundwater potential zones in Theni district, Tamil Nadu, using remote sensing, GIS and MIF techniques. Geoscience Frontiers. doi:10.1016/j.gsf.2011.10.007

Magowe M, Carr JR. 1997. Relationship between lineaments and ground water occurrence in western Botswana. Ground Water, Vol. 37, No. 2, pp. 282-286.

Marr D. Hildreth E. 1980. Theory of edge detection. Proc. R. Soc. Lond. Ser. B Biol. Sci. 207, 187217

Meijerink AMJ. 2007. Remote sensing applications to groundwater. IHP-VI, series on groundwater no. 16, UNESCO 2007; 
Ndong BF, Ntomba SM, Messi EJ, Okia D, Mvondo JO. 2014. Définition structurale des linéaments par traitement d'image satellitaire: cas du massif de Ngovayang (Sud Cameroun). Afrique SCIENCE 10(3) (2014) 107 - 112. ISSN 1813-548X

Ndehedehe CE, Awange J, Kuhn M, Agutu N, Fukuda Y. 2017. Climate teleconnections influence on West Africa's terrestrial water storage. Hydrol. Process. 31 (18), 3206-3224. https://doi.org/10.1002/hyp.11237.

Ndehedehe CE, Burforda MA, Stewart-Koster B, Bunn SE. 2020. Satellite-derived changes in floodplain productivity and freshwater habitats in northern Australia (1991-2019). Ecological Indicators 114 (2020) 106320. https://doi.org/10.1016/j.ecolind.2020.106320

Niipele JN, Chen J. 2019. The usefulness of ALOS-PALSAR DEM data for drainage extraction in semi-arid environments in The Iishana sub-basin. Journal of Hydrology: Regional Studies. Vol. 21, pp.57-67. doi.org/10.1016/j.ejrh.2018.11.003

Ojha C, Werth S, Shirzaei M. 2019. Groundwater loss and aquifer system compaction in San Jôaquin Valley during 2012-2015 drought. Journal of Geophysical Research: Solid Earth, 124,31273143. https://doi.org/10.1029/2018JB016083

Okioh L. 1972. Contribution à l'étude morphologique des reliefs résiduels de la région de DassaZoumé, Fita et Savalou (Dahomey). Thèse de doctorat, Université de Paris VII, Paris, 163 p.

Oussou EF, Oloukoi J, Yalo N, Boukari M. 2019. Analyse Spatiale du potentiel en eau souterraine dans le bassin du Zou au Sud du Benin (Afrique de L'ouest). European Scientific Journal, Vol.15, No.27 ISSN: 1857 - 7881. doi:10.19044/esj.2019.v15n27p402

PCI. Geomatica Version 10.3 User's Manual. PCI Geomatics Enterprises: Richmond Hill, ON, Canada, 2009.

Persendt FC, Gomez C. 2016. Assessment of drainage network extractions in a low-relief area of the Cuvelai Basin (Namibia) from multiple sources: LiDAR, topographic maps, and digital aerial orthophotographs Geomorphology. p. 32

Pirotti F, Tarolli P. 2010. Suitability of LiDAR point density and derived landform curvature maps for channel network extraction. Hydrol. Process., 24 (2010), pp. 1187-1197, doi.org/10.1002/hyp.7582

Pougnet RS. 1957. Le Précambrien du Dahomey. Bull. Dir. fédér. Min. Afr. occ. fr., Dakar, 186p.

Rahnama M, Gloaguen R. 2014. TecLines: A MATLAB-Based Toolbox for Tectonic Lineament Analysis from Satellite Images and DEMs, Part 1: Line Segment Detection and Extraction. Remote Sens. 6, 5938-5958; doi:10.3390/rs6075938. ISSN 2072-4292.

Rahnama M, Gloaguen R. 2014. TecLines: A MATLAB-Based Toolbox for Tectonic Lineament Analysis from Satellite Images and DEMs, Part 2: Line Segments Linking and Merging. Remote Sens. 6, 11468-11493; doi:10.3390/rs61111468. ISSN 2072-4292.

Sandi SG, Saco PM, Rodriguez JF, Saintilan N, Wen L, Kuczera G, Riccardi G, Willgoose G. 2020. Patch organization and resilience of dryland wetlands. Science of The Total Environment. Volume 726, 138581, ISSN 0048-9697, https://doi.org/10.1016/j.scitotenv.2020.138581. 
Savané I. 1997. Contribution à l'étude géologique et hydrogéologique des aquifères discontinus du socle cristallin d'Odienné (Nord-Ouest de la Côte d'Ivoire). Apport de la télédétection et d'un système d'information géographique à référence spatiale. Thèse de Doctorat d'Etat ès Sciences Naturelles. Univ. Cocody (Côte d'Ivoire). 332 p.

Shankar B. Tornabene LL, Osinski GR, Roffey M, Bailey JM, Smith D. 2016. Automated lineament extraction technique for the Sudbury impact structure using remote sensing datasets- an update. 47th Lunar and Planetary Science Conference. p2

Stanislawski LV, Survila K, Wendel J, Liu Y, Buttenfield BP. 2018. An open source highperformance solution to extract surface water drainage networks from diverse terrain conditions. Cartogr. Geogr. Inf. Sci., 45 (2018), pp.319-328. doi.org/10.1080/15230406.2017.1337524

Tagnon BO, Lasm T, Douagui AG, Savané I. 2016. Statistical and Geostatistical Analysis of Lineaments Network Mapped in The Precambrian Basement: Case of Divo-Oume Region (Southern Cote d'Ivoire). European Scientific Journal, vol.12, No.33 ISSN: 1857 - 7881. doi: 10.19044/esj.2016.v12n33p299

Tarolli P, Giulia S, Dalla Fontana G. 2012. Geomorphic features extraction from high-resolution topography: landslide crowns and bank erosion. Nat. Hazards, 61 (2012), pp. 65-83, doi.org/10.1007/s11069-010-9695-2

Tran NH. 2004. Characterisation and modelling of naturally fractured reservoirs. PhD. Thesis at University of New South Wales, Sydney, Australia, p227

Vision Eau Bénin. 1999. Vision Eau Bénin 2025. Document final, Décembre 1999.

Wyns R, Baltassat JM, Lachassagne P, Legtchenko A, Vairon J. 2004. Application of proton magnetic resonance soundings to groundwater reserves mapping in weathered basement rocks (Brittany, France). Bull. Soc. Géol. Fr., 175. 2134.

Yang D, Shao W, Yeh PJ-F, Yang H, Kanae S, Oki T. 2009. Impact of vegetation coverage on regional water balance in the nonhumid regions of China, Water Resour. Res., 45, W00A14, doi:10.1029/2008WR006948.

Yao KT, Oga M-S, Kouadio KE, Fouché O, Ferriere G, Pernelle C. 2014. Rôle hydrogéologique des linéaments structuraux en milieu cristallin et cristallophyllien: cas du bassin versant du Sassandra, Sud-Ouest de la Côte d'Ivoire. Afrique Science 10(4) (2014) 78 - 92. ISSN 1813$548 \mathrm{X}$

Youan Ta M, Lasm T, Jourda JP, Kouamé KF, Moumtaz R. 2008. Cartographie des accidents géologiques par imagéries satellitaire Landsat-7 ETM+ et analyse des réseaux de fractures du socle précambrien de la région de Bondoukou (Nord-Est de la Côte d'Ivoire). Télédétection, Editions scientifiques GB, 8(2), pp119-135. <halshs-00392312>

Zazoun RS. 2008. The Fadnoun area, Tassili-n-Azdjer, Algeria: Fracture network geometry analysis. Journal of African Earth Sciences, Vol. 50, N5, pp. 273-285

Ziou D. 1991. Line detection using an optimal IIR filter. Pattern Recognition 1991, 24, 465-478. 